\title{
EL CONSTITUCIONALISMO DEL SEXENIO EN EL CONTEXTO CONSTITUCIONAL EUROPEO DE MEDIADOS DEL SIGLO XIX Referencia específica al influjo del modelo belga
}

\author{
ANDONI PÉREZ AYALA \\ Profesor Titular de Derecho Constitucional \\ Universidad del Pais Vasco
}




\section{SUMARIO}

INTRODUCCIÓN. LA EXPERIENCIA CONSTITUCIONAL DEL SEXENIO Y EL ENTORNO CONSTITUCIONAL EUROPEO DE LA ÉPOCA. I. LA CONSTITUCIÓN BELGA DE 1831 Y EL NUEVO CICLO CONSTITUCIONAL EN EUROPA A PARTIR DE 1830. 1. La apertura de un nuevo ciclo constitucional: La Charte orleanista de 1830. 2. La singularidad de la experiencia constitucional belga de 1831. 3. Las influencias exteriores en la Constitución belga de 1831. 4. La novedades en la estructura formal del texto constitucional. 5. Innovaciones en el contenido constitucional: derechos y libertades; organización institucional $y$ revisión constitucional. II. LA CONSTITUCIÓN DE 1869 Y EL INFĻUJO DEL MODELO CONSTITUCIONAL BELGA DE 1831. 1. El influjo generalizado del modelo belga en Europa en el siglo XIX y su repercusión en nuestro constitucionalismo histórico: la nonata de 1856. 2. El movimiento de 1868 y el referente belga. 3. La estructura formal del texto constitucional de 1869. 4. La reformulación constitucional de los derechos y libertades. 5. La reconfiguración institucional de los poderes y la parlamentarización de la Monarquía. 5.1. Las Cámaras parlamentarias. 5.2. El Rey y los Ministros. 6. La remodelación del poder judicial. 7. Las instituciones locales. 8. La reforma constitucional. 


\title{
EL CONSTITUCIONALISMO DEL SEXENIO EN EL CONTEXTO CONSTITUCIONAL EUROPEO DE MEDIADOS DEL SIGLO XIX Referencia específica al influjo del modelo belga
}

\author{
POR \\ ANDONI PÉREZ AYALA \\ Profesor Titular de Derecho Constitucional \\ Universidad del País Vasco
}

\section{INTRODUCCIÓN. \\ LA EXPERIENCIA CONSTITUCIONAL DEL SEXENIO Y EL ENTORNO CONSTITUCIONAL EUROPEO DE LA ÉPOCA}

El sexenio que se abre a partir del triunfo de la gloriosa Revolución de Septiembre de 1868 constituye uno de los períodos más sugestivos desde el punto de vista político del siglo XIX. Si bien su limitación temporal, que en realidad se reduce a poco más de un quinquenio (hasta el inicio del año 1874) ${ }^{1}$ hace que estos años no pasen de ser un

1 La disolución de la Cortes por el General Pavía, el 3 de enero de 1874, pone fin a este período, un año antes de que el pronunciamiento del General Martínez Campos (29 de diciembre de 1874) restaurase oficialmente la Monarquía alfonsina. El texto de los Decretos de disolución de las Cortes (8 enero 1874), de cons- 
breve paréntesis entre los dos dilatados períodos históricos que le preceden y le suceden - el período isabelino y la restauración alfonsina-, su significación en nuestra accidentada historia política y constitucional del siglo XIX trasciende ampliamente su corta duración temporal. 1868 representa, junto con 1812 y 1931, los tres momentos históricos en que se abren expectativas de profundos cambios políticos, que sin embargo se verán frustradas rápidamente en todos los casos por el curso de los acontecimientos.

Como no podía ser de otra forma, las expectativas de profundos cambios políticos abiertas por la revolución de 1868 iban a tener repercusión directa en el plano constitucional a través de la obra del constituyente de 1869. En la panorámica global del constitucionalismo español del siglo XIX2 , la experiencia constitucional del sexenio supone un auténtico punto de inflexión, introduciendo importantes novedades en relación con el constitucionalismo histórico precedente. Como tendremos ocasión de comprobar a lo largo de estas líneas, son numerosas e importantes las innovaciones que hay que anotar en el haber del constitucionalismo democrático del sexenio, tanto en el terreno de los derechos y libertades, cuyo ámbito se verá ampliado sensiblemente, como en lo relativo al sistema institucional, en especial por lo que se refiere a la reconfiguración de la institución monárquica en él.

No es posible, sin embargo, comprender adecuadamente el significado y el alcance de las innovaciones introducidas por el sexenio, así como el nuevo modelo constitucional en su conjunto, al margen del contexto constitucional en la Europa de mediados del siglo XIX, en cuyo marco es preciso situar la singular experiencia constitucional de 1869. Aunque suele ser bastante frecuente abordar el examen de los textos constitucionales al margen de su contextualización en marcos globales más amplios, tanto desde el punto de vista geográfico como histórico, no cabe duda que este necesario encuadramiento nos pro-

titución del Ministerio-Regencia (31 diciembre 1874) y de convocatoria de nuevas Cortes, de esta misma fecha, pueden verse en Diego SEvilla ANDRÉs: Constituciones y otras Leyes y Proyectos Politicos de España, Ed. Nacional, Madrid, 1969, págs. 573,579 y 581 .

2 Como obras generales de referencia sobre el constitucionalismo histórico español, vid., entre otras, L. SÁnCHEZ AGESTA: Historia del constitucionalismo español (1808-1936), C.E.C., Madrid, 1984; F. FernÁndez Segado: Constituciones históricas españolas, Civitas, Madrid, 1986, y, asimismo, la obra de síntesis de J. TOMAS VILlARroYa: Breve historia del constitucionalismo español, C.E.C., Madrid, 1985. 
porciona una referencia comparativa que, si siempre es aconsejable, a veces resulta indispensable para poder comprender adecuadamente las experiencias constitucionales en su singularidad. Como señala acertadamente Biscaretti, tales referencias comparativas no sólo sirven para tener un conocimiento más amplio y extenso de las experiencias constitucionales en otros países sino también, $y$ de forma muy especial, para tener un mejor conocimiento de las propias ${ }^{3}$.

Esta aseveración, que tiene validez con carácter general, tiene especial aplicación en casos como el nuestro en que, por razones históricas, hemos sido receptores, más que emisores, de influencias constitucionales. Así, no sólo el constitucionalismo del sexenio, que como veremos más adelante experimenta el influjo de otros modelos constitucionales de la época, especialmente del belga de 1831, sino también las experiencias constitucionales anteriores y posteriores, que también se nutrieron, en diversa medida, de influencias exteriores. Tal es el caso desde nuestra primera Constitución de Cádiz, en la que puede apreciarse el influjo de la francesa de 17914; y con anterioridad, la de Bayona de 1808, impuesta por Napoleón, en la que el referente será la también francesa del año III (1795); o posteriormente, el Estatuto real de 1834, en el que el modelo de referencia será el de las Cartas otorgadas de la Restauración ${ }^{5}$, que a su vez, será sustituido, a continuación (a partir de 1837) por el de la Charte orleanista de 1830 y el de la Constitución belga de 1831; sin olvidarnos del influjo que ejercerá de forma permanente a lo largo de todo el siglo XIX el modelo constitucional británico, a pesar de su excepcional singularidad que impide la imitación; finalmente, la Constitución republicana de 1931, que debe ser encuadrada en el constitucionalismo social de entreguerras y en la que se deja sentir claramente la influencia de la Constitución alemana de Weimar de $1919^{6}$. En definitiva, no es posible entender la evo-

3 P. BISCARETTI DI RUFFIA: Introducción al Derecho constitucional comparado, Fondo de Cultura Económica, México, 1996, pág. 80.

4 Vid. I. Fernandez Sarasola: "La Constitución española de 1812 y su proyección europea e iberoamericanan, en particular el apartado referente a la recepción de los modelos constitucionales foréneos, en Fundamentos, $n .^{\circ} 2 / 2000$, monográfico sobre Los modelos constitucionales en la Historia comparada, Junta General del Principado de Asturias, Oviedo, 2000, págs. 259 y ss.

5 Vid. J. TOMÁs VILLARROYA: El sistema político del Estatuto real (1834-1836), Instituto de Estudios Políticos, Madrid, 1976, págs. 95 y ss.

6 Vid. J. CoRcuera: "La Constitución española de 1931 en la historia constitucional comparada", en particular el apartado relativo al constitucionalismo de entreguerras y su reflejo en la Constitución de la II República española, en Modelos constitucionales en la Historia comparada, op. cit., págs. 634 y ss. 
lución de nuestro constitucionalismo al margen del contexto constitucional europeo de cada época y de las variadas influencias de las que ha sido receptor, en especial en los momentos más estelares, en los que mayores expectativas de cambio político se abrian como era el caso en la coyuntura de 1868-69.

No se trata de un fenómeno exclusivo de nuestro país, ni de ningún otro en particular. La interacción constitucional es consustancial a la propia evolución del constitucionalismo desde su nacimiento; e incluso antes, durante su período de gestación en la Gran Bretaña del siglo XVIII, cuya influencia en los nacientes regímenes constitucionales de USA y Francia no puede ser obviada ${ }^{7}$. Conviene tener presente que el constitucionalismo, a diferencia de otros fenómenos juridicos que se ciñen a ámbitos territoriales o sectoriales limitados, va a tener una vocación universalizadora desde su nacimiento, a finales del siglo XVIII. Y si bien habrán de transcurrir dos siglos hasta que, tras la descolonización en el curso de la segunda mitad del siglo $\mathrm{XX}$, se haga efectiva la universalización del constitucionalismo, ello no impide que en determinadas áreas geográficas y períodos históricos se desarrollen procesos de interacción entre las diversas experiencias constitucionales. Tal será el caso de las experiencias constitucionales que se suceden en las décadas centrales del siglo XIX (desde 1830 hasta la década de los setenta) en el área euroatlántica, escenario en el que el constitucionalismo contemporáneo va a tener su primera implantación.

Es en este contexto en el que se va a ubicar la singular experiencia constitucional del sexenio, centrando nuestra atención en el examen de las relaciones con el constitucionalismo de este período y el influjo que ejercieron en ella los modelos más influyentes de la época. No se trata, por tanto, y asi hay que advertirlo desde el principio, de hacer un análisis sistemático del texto constitucional de 1869, tema sobre el que ya existe una amplia bibliografía ${ }^{8}$, sino de abordar esta singular experiencia constitucional desde una perspectiva históricocomparativa, en el marco del constitucionalismo europeo de mediados del siglo XIX; lo que, sin duda, contribuirá a proporcionar una

7 Es ilustrativa al respecto la obra clásica de J. L. DE K'OLME: La Constitution d'Angleterre, publicada inicialmente en 1771. Existe una edición actualizada en castellano, acompañada de un amplio estudio introductoria de B. Clavero, Centro de Estudios Constitucionales, Madrid, 1992.

8 Vid., en particular, A. CARRO: La Constitución española de 1869, Ed. Cultura Hispánica, Madrid, 1952. 
visión más amplia y completa de la original obra del constituyente de 1869.

Las influencias exteriores de las que fue receptor el constituyente de 1869 fueron variadas; cabe reseñar entre ellas la francesa (Charte orleanista de 1830 y Constitución republicana de 1848) ya que todos los acontecimientos al otro lado de los Pirineos repercutieron en nuestra vida política $y$, además, Francia fue el refugio natural de casi toda la emigración política española a lo largo del siglo XIX; asimismo, la británica, cuyo modelo de Monarquía en proceso de parlamentarización durante el XIX servirá de referente a las Monarquías europeas, entre ellas la española a mediados del XIX. Hay que añadir ahora a los dos referentes clásicos ya mencionados -el francés y el británico- el americano, que constituye una novedad y que ejercerá un influjo nada desdeñable sobre el constituyente de 1869 . Finalmente, es preciso hacer una mención especial a la Constitución belga de 1831 que, como veremos a lo largo de estas líneas, tuvo una influencia determinante en la configuración del modelo constitucional del sexenio.

Es este último el tema que va a centrar nuestra atención en las líneas que siguen a continuación; y ello por dos motivos: en primer lugar, por las importantes similitudes, que en algunos casos resultan sorprendentes, que pueden apreciarse entre la Constitución belga de 1831 y la nuestra de 1869 , lo que revela el indudable influjo que aquélla ejerció sobre ésta. A este hecho hay que añadir la ausencia de estudios específicos sobre el tema, que contrasta con los dedicados al examen de otras influencias exteriores, en particular la americana ${ }^{9}$, en el constitucionalismo del sexenio. Se pretende así contribuir a cubrir esta laguna en el estudio de uno de los textos más emblemáticos de nuestro constitucionalismo histórico desde una perspectiva comparativa.

Ello nos obliga a hacer una referencia inicial al contexto constitucional de la Europa del siglo XIX, en particular a partir de 1830, momento en el que se abre el ciclo del constitucionalismo liberal. En este marco, es preciso dedicar una atención especial a la constitución belga de 1831, sin duda el documento más innovador y que mejor plasma las nuevas concepciones constitucionales de la época, lo que unido a su prolongada continuidad explica el fuerte influjo que va a ejercer a lo largo de todo el siglo XIX en otros textos constitucionales

9 Vid. al respecto la obra monográfica de J. OLTRA: La influencia norteamericana en la Constitución española de 1869, Instituto de Estudios Administrativos, Madrid, 1972. 
europeos, entre ellos nuestra Constitución de 1869. A continuación, se abordará el estudio de ésta desde una perspectiva histórico-comparativa, centrando nuestra atención en el examen de los elementos innovadores que introduce en nuestro constitucionalismo histórico y su relación con la influencia que el modelo constitucional belga ejerció sobre nuestro constituyente de 1869.

\section{LA CONSTITUCIÓN BELGA DE 1831 Y EL NUEVO CICLO CONSTITUCIONAL EN EUROPA A PARTIR DE 1830}

\section{La apertura de un nuevo ciclo constitucional: la Charte orleanista de 1830}

La Constitución belga de 1831 es uno de los textos constitucionales que mayor influencia ha ejercido en el constitucionalismo europeo del siglo $X I X$, en particular en las décadas centrales del siglo. Su contribución a la parlamentarización de la Monarquía constitucional, en una época en la que éste era el modelo ampliamente dominante en Europa, hace de ella un referente insoslayable para comprender la evolución del constitucionalismo europeo en el siglo XIX. También en España se dejará sentir su influjo, que tendrá su primera manifestación ya en la Constitución de 1837 y de forma más clara en la nonata de 1856; pero será en el constitucionalismo democrático del sexenio, y en particular en la Constitución de 1869 , donde su proyección hallará plasmación efectiva en nuestro constitucionalismo en la forma que se examinará a continuación ${ }^{10}$.

La década de los años treinta del siglo XIX se abre con la aparición de un nuevo ciclo constitucional, el del constitucionalismo liberal, que tendrá en la Constitución belga de 1831 una de sus expresiones más emblemáticas. Tras el ciclo inicial del constitucionalismo revolucionario francés en la última década del siglo XVIII, seguido de la confusa y contradictoria experiencia "constitucional» napoleónica hasta 1815 y, finalmente, la reacción restauradora a partir de esta fecha,

10 Hay coincidencia generalizada entre todos los tratadistas de nuestro constitucionalismo histórico en señalar la influencia belga, junto a la americana, en la Constitución de 1869; aunque como ya se ha indicado, y salvo algunas referencias puntuales en la obra ya reseñada de A. CARRo, no existe ningún estudio monográfico sobre el tema. 
el inicio de la década de los años treinta va a conocer el surgimiento de nuevas experiencias constitucionales que es preciso encuadrar en el marco del proceso de consolidación del Estado liberal en Europa ${ }^{11}$. Este panorama constitucional de la época debe ser completado con la referencia al constitucionalismo americano, al otro lado del Atlántico, y al británico, al otro lado del canal. Pero en ambos casos, y sin soslayar la influencia que ambos van a ejercer sobre el constitucionalismo continental europeo durante el siglo XIX, en particular el británico por lo que se refiere a la configuración de la Monarquía parlamentaria, es preciso constatar que se trata de dos modelos que presentan caracteristicas muy singulares, así como modalidades de evolución y desarrollo dispares en relación con el constitucionalismo continental europeo.

En la Europa continental será en Francia, como antes lo fue en 1789, luego con Napoleón y después con la Restauración, donde surgen las primeras manifestaciones de cambio del ciclo constitucional, que hallarán su plasmación en la Charte orleanista de 1830. Planteada formalmente como una reforma de la anterior Charte de 1814, de la que reproduce el mismo esquema y numerosas disposiciones en los mismos términos ${ }^{12}$, introduce, sin embargo, una serie de elementos nuevos que contribuirán a dotar al modelo monárquico vigente hasta entonces de una nueva configuración. En palabras expresivas de $M$. García Pelayo, la Charte de 1830 imantiene todas las partes del anterior edificio constitucional, pero no deja a ninguna exactamente como estaba» ${ }^{13}$. En particular, por lo que se refiere a la reconfiguración de la Monarquía con criterios de signo tendencialmente parlamentarios, entre los que cabe reseñar, siguiendo a Barthélemy y Duez, la designación por el Rey de los ministros entre los miembros de la mayoría parlamentaria y la retirada del Gabinete cuando no es respaldado por ésta, el uso por el Gobierno del derecho de disolución del Parlamento, la fiscalización de la política gubernamental mediante la interpelación parlamentaria... A ello hay que añadir la limitación de los poderes reales, tanto de la potestad reglamentaria como de la iniciativa

11 Sobre este ciclo constitucional, así como sobre la sucesión de ciclos constitucionales durante el siglo XIX, vid. P. BISCARETTI, op. cit., págs. 509 y ss.

12 Para los textos constitucionales franceses se ha utilizado la versión de M. DuVerger: Constitutions et Documents politiques, PUF, París, 1978.

13 M. García Pelayo: Derecho Constitucional Comparado, capítulo dedicado al "Derecho Constitucional de la República Francesa», Alianza Universidad, Madrid, 1984, pág. 479. 
legislativa, y la tímida ampliación del cuerpo electoral para la elección de diputados ${ }^{14}$.

La Charte orleanista de 1830, además del destacado lugar que ocupa en el laboratorio de experiencias constitucionales que se suceden en Francia a lo largo del siglo que transcurre entre 1789 y $1885^{15}$, va a tenèr también una importante proyección exterior en el constitucionalismo europeo de la época, incluido el constitucionalismo español, cuyos textos de 1837 y 1845 (aunque en este último caso desde posiciones distintas al anterior) no son ajenos al influjo orleanista. Más allá de aspectos puntuales en su articulado, el factor determinante residía en el intento de conciliar el principio monárquico con el parlamentario y en las expectativas que abría la parlamentarización de la Monarquía ${ }^{16}$. Pero será en Bélgica donde estas expectativas abiertas por la Charte orleanista de 1830 sobre la parlamentarización de la Monarquía cuajen con mayor solidez y tengan una formulación más elaborada en términos jurídico-políticos, a través de la obra del constituyente beiga de 1831 .

Aunque la Constitución belga de 1831 comparte con la Charte orleanista francesa de 1830 un mismo escenario temporal, lo que ha conducido a caracterizarla con criterios cronológicos como "una Constitución del tiempo de Luis-Felipen; $y$, además de esta coincidencia cronológica, ambos cambios constitucionales tienen su origen en un movimiento social y político de características comunes (París, julio 1830; Bruselas, agosto-septiembre 1830), conviene advertir desde el primer momento que, a pesar de las indudables relaciones existentes entre ambos, se trata de dos textos constitucionales de distinta naturaleza y características. Como observa $L$. Lacché en el estudio comparado de ambos textos, es preciso "superar el nexo cronológico y formal que pretende que la Constitución belga es una especie de "heredera" más o menos directa de las doctrinas y prácticas constitucionales francesas de la Restauración y, en particular, del texto orlea-

14 J. Barthelemy y P. Duez: Traitè elementaire de Droit Constitutionnel, Dalloz, París, 1933, pág. 176.

15 Cfr. P. PASQUiNo: "La Teoria costituzionale de la Monarchia de Luglion, en AA.VV., Materiali per una Storia della Cultura Giuridica, n. ${ }^{\circ} 2-1988$, págs. 377 y ss.

16 Vid. L. LACCHE: «Constitución, Monarquía, Parlamento. Francia y Bélgica ante los problemas y modelos del constitucionalismo europeo (1814-1848)", en particular el Ap. VI: "Vive la Charte! La Constitución orleanista de 14 de Agosto de 1830 ", en Modelos constitucionales en la Historia comparada, op. cit., págs. 499 y ss. 
nista", insistiendo a continuación en la especificidad de la Constitución belga y en la necesidad de deshacer "el equivoco de naturaleza constitucional que ha provocado que se repitiera por mucho tiempo la vulgata de una "natural» filiación de la Constitución belga de 1831 respecto de la Charte de 1830 »17.

Por otra parte, y en relación con el otro referente constitucional de la época en Europa, Gran Bretaña, con la que también se encuentra emparentada políticamente Bélgica hasta el punto de ser conocida entonces como la petite Angleterre ${ }^{18}$, el modelo constitucional belga va a aportar la novedad de ofrecer un texto articulado y codificado que formaliza mejor que ningún otro, en términos jurídico-políticos, el proceso de parlamentarización de la Monarquía que se está desarrollando en ese momento en Europa. De esta forma, el modelo constitucional belga conecta directamente con los dos grandes referentes constitucionales europeos - el francés y el británico- pero presentando, al mismo tiempo, características propias y distintivas. Es a partir de este encuadre en el constitucionalismo europeo de los años treinta del XIX como puede abordarse el significado de la experiencia constitucional belga de 1831, en especial por lo que se refiere a la influencia y la proyección que tuvo en el constitucionalismo europeo de mediados del siglo XIX, incluido el español.

\section{La singularidad de la experiencia constitucional belga de $\mathbf{1 8 3 1}$}

Varios factores van a singularizar la experiencia constitucional belga de 1831. En primer lugar, se trata de un proceso constituyente fundacional que no se limita a introducir reformas o, incluso, a instaurar un nuevo régimen político, como ocurría con la Charte orleanista, sino que funda un nuevo Estado. Es precisamente este hecho el que permite que el Estado sea moldeado desde sus orígenes de acuerdo con criterios constitucionales, y no al revés, que sea la Constitución la que tenga que amoldarse a la estructura del Estado (Charte orleanista de 1830$)^{19}$. Especial interés ofrece, en este marco fundacional, la

17 L. LACCHÉ, op. cit.., págs. 468 y 538.

18 Cfr. E. VANDENPEEREBOOM: Du gouvernement representatif en Belgique (1831-1848), Bruselas, 1856; cit. L. LACCHÉ, op. cit.

19 Sobre esta cuestión, vid. R. FUSILIER: Les Monarchies parlamentaires, Ed. Ouvrières, París, 1960, págs. 350 y ss.; en particular, el capitulo $V$ está dedicado a la Monarquía parlamentaria en Bélgica. 
configuración de la institución monárquica, decisiva en la estructura institucional en esa época, que podrá ser configurada con criterios constitucionales acordes con la forma de gobierno parlamentaria, tal y como ocurre en el modelo constitucional belga, lo que le singulariza claramente en relación con otras experiencias constitucionales de la época.

Es éste uno de los factores que van a explicar la proyección exterior y la influencia del modelo constitucional belga en otros países a mediados del siglo XIX, ya que bien se trate de la fundación de un nuevo Estado o de la remodelación de la institución monárquica en él, la referencia constitucional belga de 1831 es ineludible. Tal es el caso de situaciones tan dispares como las de Grecia (1864), Rumanía (1866), del Estatuto albertino en el Reino de Cerdeña (1848), o de la Constitución prusiana (1848-1850) ${ }^{20}$. Es también el caso, entre nosotros, de los textos constitucionales de 1837, que no es ajeno al influjo belga y en el que por primera vez tras la accidentada experiencia de la Constitución de 1812 se intentaba la inserción de la Monarquía en el esquema constitucional; de la nonata de 1856, que comportaba un importante cambio del modelo de 1845 que afectaba especialmente al papel de la institución monárquica en el sistema constitucional; $y$, sobre todo, lo será en la Constitución de 1869, que va a suponer la remodelación global de la Monarquía de acuerdo con los nuevos criterios del constitucionalismo democrático.

Otro de los rasgos que caracterizan la obra del constituyente belga de 1831 es que va a ser producto de un movimiento que tanto por su composición social, agrupando a sectores de la burguesía que hasta entonces no habían tenido protagonismo político, como por los objetivos de signo democrático y liberal que perseguia frente al régimen de la Restauración, conducía necesariamente a un cambio político que habia de tener su plasmación en un nuevo modelo constitucional. A este respecto, es preciso reseñar que este movimiento sociopolítico que da lugar al cambio constitucional de comienzos de la década de los años treinta presenta características comunes en Francia y en Bélgica, donde se desarrolla de forma casi simultánea durante el verano de 1830 (en julio en París, en agosto-septiembre en Bruselas); ello explicará las similitudes que pueden observarse entre el régimen instaurado en Francia por la Charte orleanista de 1830 y en cit., pág. 510 .

20 Cfr. P. BIsCARETTI: Introducción al Derecho Constitucional comparado, op. 
Bélgica por la Constitución de 1831. Hay que puntualizar, no obstante, que en Bélgica, junto a los factores comunes señalados relativos al carácter liberal-democratizador del movimiento que exigía el cambio político, hay que añadir el factor distintivo nacional que da lugar al nacimiento del nuevo Estado belga ${ }^{21}$.

A la vista de estos orígenes constitucionales a los que nos hemos referido, no es de extrañar que cuando en otros países europeos surjan movimientos similares, agrupando a sectores sociales que reivindiquen un protagonismo político que hasta entonces no han podido jugar y reformas del sistema político de signo liberal y democrático, en especial por lo que se refiere a la remodelación de la institución monárquica, el referente constitucional sea necesariamente el modelo que surge en Francia y Bélgica en 1830-3122; y en especial, el texto constitucional belga ya que, además de estar mejor construido formalmente y ser más completo en su contenido (la Charte de 1830 era una reforma de la Carta otorgada de 1814), será un texto que permanecerá vigente ininterrumpidamente durante todo el siglo XIX (la Charte dejará de tener vigencia a partir de 1848). Así ocurrirá efectivamente en buena parte de los países europeos que, a lo largo del siglo XIX, se plantean cambios en su sistema político. $Y$ en particular en España, donde ya en 1856, al elaborarse la nonata, se tendrá en cuenta la experiencia belga de 1831; pero de forma más clara en el movimiento que desembocará en la gloriosa de 1868, que hallará en la Constitución belga el modelo de referencia para reconfigurar la Monarquía haciéndola compatible con la forma de gobierno parlamentaria.

\section{Las influencias exteriores en la Constitución belga de 1831}

A pesar del carácter innovador que presenta la Constitución belga, no sólo en el momento de su nacimiento (1831) sino también a lo largo de todo el siglo XIX como lo muestra la influencia que ejerció sobre otros textos constitucionales de la época, se trata de una Constitución que recoge, en diversa medida, elementos de otras Constitu-

21 Sobre este período, vid. X. MABILLE: Histoire politique de la Belgique, CRISP, Bruselas, 1986, págs. 94 y ss.; para un tratamiento más amplio, vid. la obra de referencia de H. PIRENNE: Histoire de la Belgique, des origines à nos jours, t. IV, Bruselas, 1974.

22 Cfr. B. MiRkine-Guetzevitch: Les Constitutions européennes, PUF, París, 1951, pag. 26. 
ciones. Entre ellas cabe reseñar, en primer lugar, la Charte orleanista francesa de 1830 , sin duda el texto con el que tiene una relación más estrecha dada la proximidad temporal del momento en que se aprueban ambos textos y las conexiones entre los movimientos que dan lugar a los cambios constitucionales en Francia y Bélgica en 1830-31. Según las estimaciones de J. Gilissen, aproximadamente un tercio de las disposiciones constitucionales belgas proceden la Charte francesa de 1830 , que a su vez, como señala este autor, proceden parcialmente de la Carta otorgada de 1814, reformada por aquélla23. En cualquier caso, el referente principal de la Constitución belga de 1831 es la referida Charte de Luis-Felipe, que así podrá tener proyección en el constitucionalismo europeo de mediados del siglo XIX, en particular por lo que se refiere a la configuración de la institución monárquica, a través de aquélla; sobre todo, después de 1848 , momento en el que deja de tener vigencia.

Otro de los referentes del constituyente belga de 1831 fue el modelo constitucional británico, que ejerció una influencia indudable en la configuración de la institución monárquica. Es muy ilustrativa a este respecto la denominación que se utiliza para referirse a Bélgiça en esta época - la petite Angleterre - en referencia a la similitud entre sus regímenes políticos. La peculiaridad del modelo constitucional británico, carente de formalización en un texto codificado y basada sobre todo en sus propias convenciones constitucionales, hace difícil precisar las disposiciones de procedencia británica así como cuantificar su incidencia en el texto constitucional belga; pero, en cualquier caso, la influencia británica no ofrece duda alguna ${ }^{24}$. Es precisamente en ello donde radica una de las principales aportaciones de la Constitución belga al constitucionalismo europeo del siglo XIX, como es la formalización y codificación en un texto constitucional articulado del diseño de la Monarquía parlamentaria; o para ser más preciso, de la Monarquía constitucional en proceso de parlamentarización, que tendrá su expresión más acabada y completa en el texto constitucional belga. Ello ayuda a explicar el influjo que ejerció en otros países (incluida España), donde la cuestión de la parlamentarización de la Monarquía será una de las principales planteadas a lo largo de todo el siglo XIX.

23 Cfr. J. GILISSEN: «La Constitution belge de 1831: ses sources, son influencen, Res Publica, vol. X, 1968, págs. 107 y ss.

24 Sobre este tema, vid. D. R. WATSON: "The British Parlamentary System and the Growth of Constitutional Government in Western Europe", en C. J. BARTLETT, Britain Pre-eminent Studies of British World Influence in the Nineteenth Century, Macmillan, Londres; 1969, págs. 101 y ss. 
También puede observarse la existencia en el texto constitucional belga de disposiciones provenientes del primer constitucionalismo francés de la última década del XVIII; en particular de la Constitución de 1791, de la que, según J. Gilissen, procederían directamente alrededor de un $10 \%$, relativas principalmente a la limitación del poder real y a algunas libertades fundamentales. Interesa reseñar este componente ya que ello singulariza al modelo constitucional belga en relación con el orleanista y el británico, emparentándole con el modelo, más próximo al de los inicios revolucionarios del constitucionalismo continental europeo, de la "Monarquía nacional»25, cuya expresión será la Constitución de 1791 (y entre nosotros, la de Cádiz de 1812). De ella toma, además, algunos elementos estructurales tales como el principio de soberanía nacional y el de supremacía constitucional, desconocidos en la Charte orleanista francesa y en el modelo británico, y que constituirán rasgos distintivos del modelo constitucional belga originario.

Por último, hay que reseñar la presencia de elementos procedentes de la Ley Fundamental (Grondwet) de los Países Bajos de 1815, lo que es debido al hecho de la pertenencia de Bélgica al Reino Unido de los Países Bajos durante el período anterior a su independencia (1815-1830). Si bien el espacio ocupado en el texto constitucional belga por estas disposiciones es apreciable en términos cuantitativos ${ }^{26}$, no puede afirmarse, sin embargo, que sean decisivas en la determinación del modelo constitucional belga, cuya orientación y referentes, como se ha señalado anteriormente, divergen por completo del modelo de la Restauración, en el que hay que inscribir la Grondwet de 1815. Por el contrario, será precisamente la propia Constitución belga de 1831 la que influirá posteriormente en la evolución constitucional holandesa, cuando este país emprenda reformas en su sistema político de signo liberal democrático.

Hay, finalmente, según J. Gilissen, un $10 \%$ aproximadamente de disposiciones constitucionales originales; $y$ entre ellas, una decena de artículos realmente innovadores que afectan a cuestiones clave, tales como la constitucionalización por primera vez del derecho de asociación, la libertad de enseñanza y las relaciones Iglesia-Estado, cuestión ésta de gran relevancia en Bélgica (que luego tendrá también una

25 Cfr. J. M. Porras Ramírez: Principio democrático y función regia en la Constitución normativa, Tecnos, Madrid, 1995, pág. 103.

26 J. GILISSEN, op. cit., llega a estimarlo, quizá de forma exagerada, en un $40 \%$. 
importancia creciente en otros países europeos; y muy especialmente en España, como se verá en su momento); y la previsión constitucional de un Senado electivo, lo que entonces constituía una importante novedad.

En líneas generales, la obra del constituyente belga de $1831 \mathrm{com}$ binaba, según Robert Senelle, una amalgama de corrientes políticas $Y$ filosóficas en boga en la Europa de las primeras décadas del siglo XIX, producto de las teorías y de los escritos de los grandes juristas y filósofos ingleses y franceses del siglo XVIII ${ }^{27}$. Se trataba, por tanto, de un texto constitucional de síntesis, tanto por los modelos constitucionales de referencia (principalmente el francés y el británico; y en cierta media, también el americano, aunque en este último caso, de forma más matizada) como por los principios jurídico-filosóficos que le inspiraban. Es este carácter de síntesis, aunque sobre unas bases de signo y de orientación tendencialmente democrático-parlamentaria, otro de los factores a tener en cuenta para explicar la influencia que ejerció en otros países europeos durante el siglo XIX.

\section{La novedades en la estructura formal del texto constitucional}

Por lo que se refiere a la estructura del texto constitucional desde el punto de vista formal, es preciso reseñar una serie de elementos distintivos que le singularizan en relación con otros textos coetáneos, particularmente las Cartas otorgadas de la Restauración, asi como también la Charte orleanista francesa. Con independencia de los modelos constitucionales británico y norteamericano, cuya peculiaridad en su estructura formal impide la comparación con criterios homogéneos y ciñéndonos a los textos constitucionales europeos continentales de la época, la Constitución belga de 1831 presenta una serie de rasgos característicos que la diferencian de aquéllos y que, además, serán los que acaben prevaleciendo en la sistemática de los textos constitucionales posteriores a partir de mediados del siglo XIX.

Así, tras dedicar las primeras disposiciones (Tít. I: Del Territorio y su división; arts. 1-3) a fijar el ámbito territorial, integrado por las provincias y municipios, a los que se otorga una relevancia constitucional cualificada, se pasa, seguidamente a constitucionalizar los dere-

27 R. Senelle: La reforme de l'État belge, Ministère des Affaires Étrangères, Bruselas, 1978, pág. 35. 
chos y libertades (Tít. II: De los belgas y sus derechos; arts. 4-24). A diferencia de otros textos coetáneos - Cartas de la Restauración y Charte orleanista - que carecen de una Declaración expresa de derechos y libertades, el constituyente belga de 1831 no sólo les dedica un Título específico sino que les ubica en un lugar preferente del texto constitucional, previo a las disposiciones que regulan los poderes del Estado y las relaciones entre ellos. Esta sistemática en la estructura del texto constitucional, que enlaza con el primer constitucionalismo revolucionario de la última década del XVIII ${ }^{28}$, resulta innovadora en relación con el constitucionalismo de la época en el primer tercio del siglo XIX; y será la que prevalecerá en el diseño de la estructura de los textos constitucionales a partir de entonces.

A continuación, se regulan los poderes del Estado (Tít. III, constituyendo este pasaje el grueso del texto constitucional: arts. 25-107). Interesa subrayar la sistemática que sigue el constituyente belga en la regulación de los poderes del Estado, que también difiere de la empleada en otros textos constitucionales coetáneos y que, asimismo, enlaza con el primer constitucionalismo, en particular con la Constitución de 1791, al ocuparse en primer lugar (Cap. I) de la Cámaras parlamentarias - Cámara de Representantes y Senado- y después (Cap. II) del Rey y de sus Ministros. No resulta indiferente el orden en que son tratados ambos poderes ${ }^{29}$ ya que ello refleja la prioridad que se otorga en el esquema institucional a la instancia parlamentaria, dato que ha de ser tenido en cuenta a la hora de caracterizar la orientación parlamentaria de la forma de gobierno.

Tras la regulación de los tres poderes clásicos del Estado - cabe reseñar también la completa regulación que se hace, en el contexto de la época, del poder judicial (Cap. III, arts. 92-107) - se dedica un Capítulo específico a los entes territoriales provinciales y municipales, lo que no era nada usual en el constitucionalismo de la época y revela la temprana preocupación del constituyente belga por este tema, que más tarde será objeto de regulación expresa en posteriores textos

28 Sobre este tema vid. R. MARTUCCI: «La Constitución inencontrable. Conflicto político y estabilización constitucional en Francia durante la transición de la Monarquía a la República (1789-1799)", en Modelos constitucionales en la Historia comparada, op. cit.; en particular, el apartado "A propósito de la Déclaration des droits", págs. 268 y ss.

29 La Charte orleanista, al igual que la Octroyée de 1814 , se refiere primero al Rey: "Formes de Gouvernement du Roi», a continuación a la Cámara de los Pares y, por último, a la Cámara de Diputados. 
constitucionales. Por último, la Constitución se cierra con un Título dedicado a la revisión constitucional, lo que constituye también otra importante novedad en el constitucionalismo europeo de la época, que no se ocupaba de esta cuestión ${ }^{30}$.

Esta estructura del texto constitucional, innovadora en su tiempo y precursora de la que más tarde será aceptada de forma generalizada en textos constitucionales posteriores (entre ellos, el nuestro de 1869 que, como se verá en su momento, tiene una estructura idéntica), explica la prolongada vigencia de la Constitución belga, que apenas ha sufrido modificaciones durante casi siglo y medio. Esta estabilidad constitucional, a la que no es ajena la estructura originaria del texto de 1831, contrasta con los numerosos y reiterados cambios constitucionales, en muchos casos dando lugar a la adopción de una nueva Constitución, que han caracterizado la evolución del constitucionalismo en casi la totalidad de los países europeos.

\section{Innovaciones en el contenido constitucional: derechos y libertades; organización institucional y revisión constitucional}

El carácter innovador de la Constitución belga de 1831, y el influjo que debido a ello ejerció en el constitucionalismo europeo del XIX, no se limita al diseño de la estructura del texto en los términos señalados sino que se extiende también al contenido del mismo. En este sentido, la forma como se contemplan los derechos y libertades ofrece una buena muestra de ello; no sólo su tratamiento constitucional es mucho más amplio y extenso que en cualquier otro texto del período, abarcando la totalidad de los derechos civiles propios del ideario liberal de la época, sino que además se incorporan una serie de nuevos derechos democráticos de participación política, tales como el derecho de reunión sin autorización previa (art. 19), el derecho de asociación sin medida preventiva alguna (art. 20) y el derecho de petición a las autoridades públicas (art. 21). En lo que concierne a la libertad de prensa, una de la libertades más sensibles de la época, ésta es reconocida al igual que en otros textos coetáneos pero con la particulari-

30 A diferencia del americano, donde la rigidez constitucional está presente desde el primer momento. Sobre esta cuestión, vid. P. DE VEGA:La reforma constitucional y la problemática del poder constituyente, Tecnos, Madrid, 1985; en particular, los apartados relativos a la tradición americana y la europea, págs. 38 y ss. 
dad de que este reconocimiento iba acompañado, además de la exclusión de la censura previa, de la prohibición de exigencia de fianza alguna a escritores, editores e impresores (art. 18), práctica frecuente entonces que obstaculizaba, e incluso llegaba a impedir de facto en algunos casos, el ejercicio de la proclamada libertad de prensa ${ }^{31}$.

Especial atención merece el tratamiento que se da a un cuestión especialmente polémica y controvertida en la época, como será la cuestión religiosa; y vinculada a ella, las relaciones Iglesia-Estado. Además de reconocer la libertad de cultos y su ejercicio público (art. 14) sin hacer ninguna mención específica a la Iglesia católica (tal y como se hacía en la Charte orleanista y en todos los textos constitucionales de la época) se introduce la importante novedad de impedir toda intervención del Estado en el nombramiento de los ministros de cualquier. culto (art. 16), lo que suponía una contribución decisiva a la separación efectiva entre la Iglesia y el Estado.

La libertad de enseñanza es objeto de constitucionalización expresa, lo que supone también una novedad en el constitucionalismo de la época; al igual que en otras libertades constitucionales, su reconocimiento iba acompañado una cláusula por la que quedaba "prohibida toda medida preventiva" que supusiese una restricción de la libertad de enseñanza. Es preciso puntualizar que para el constituyente belga de 1831 esta libertad estaba conectada con la libertad religiosa y con las libertades de opinión y de expresión ya reseñadas, y es plenamente compatible con la asunción por el Estado de la instrucción pública (art. 17) ${ }^{32}$.

Otra importante novedad es la referencia constitucional al empleo de las lenguas, que será facultativo y "sólo podrá ser regulado por la ley para los actos de la autoridad pública y en los asuntos judiciales" (art. 23). Se trata de una de las cuestiones que va a ser más problemática en Bélgica, dada la composición plurilingüe de la población (francófona-neerlandófona) y el conflicto lingüístico que se suscitará en torno a esta cuestión. Baste reseñar ahora la novedad de esta referencia constitucional a la cuestión lingüistica, inédita en el constitucionalismo de la época a pesar de que no faltaban países (entre ellos España) con una composición plurilingüe de su población.

31 Un comentario sobre cada una de estas disposiciones puede verse en R. Senelle: La Constitution belge commentée, Ministère des Affaires Étrangères, Bruselas, 1974, págs. 47 y ss.

32 Vid. R. Senelle, op. cit., págs. 39 y ss. 
En conjunto, puede afirmarse que nos hallamos ante un texto que contiene la declaración de derechos y libertades más amplia y mejor formulada de la época ${ }^{33}$. Ello explica la influencia que va a ejercer sobre otros textos constitucionales europeos que irán surgiendo posteriormente a lo largo del siglo XIX; y en particular, en el constitucionalismo español de mediados de siglo, especialmente durante el sexenio.

Pero si en el campo de la constitucionalización de los derechos y libertades las aportaciones fueron importantes, no menor fue su contribución a la reconfiguración de las instituciones políticas, y en particular de la Monarquía, de acuerdo con los criterios propios del modelo parlamentario. En este terreno, el referente que proporciona el modelo belga fue decisivo para avanzar en el proceso de parlamentarización de la Monarquía.

Si bien el constituyente belga de 1831 se decanta por la opción monárquica, es preciso puntualizar que se trata de un tipo de Monarquía que va a presentar unos rasgos que la diferencian claramente de los modelos vigentes en la época. Aun compartiendo algunos rasgos comunes con el modelo iniciado en la Charte orleanista francesa de 1830, desarrollará los aspectos más específicamente parlamentarios de ésta, al tiempo que conecta también con el tipo histórico de "Monarquía nacional» ${ }^{34}$ de los inicios revolucionarios del constitucionalismo continental europeo. Por otra parte, el hecho de que la instauración de la Monarquía fuese simultánea al nacimiento del nuevo Estado belga, permite configurar el modelo ex novo, sin condicionantes previos.

El propio proceso seguido en la instauración de la Monarquía pone de relieve la original peculiaridad del modelo monárquico belga. Primero se hace la Constitución y, una vez configurada en ésta la institución monárquica, se procede a continuación a elegir a su titular, el Rey; elección que, tras complejas negociaciones condicionadas por la coyuntura internacional del momento y la necesidad de respetar el equilibrio entre las potencias, recaerá finalmente en Leopoldo de Sajonia-Coburgo. Se trata de un proceso inédito en la experiencia constitucional y monárquica comparada que dará lugar a un modelo ciertamente original en el que, como señala L. Lacché, se sientan las

33 Esta opinión es compartida de forma generalizada por todos los tratadistas del tema; vid., entre otros, L. LACCHÉ: Constitución, Monarquía, Parlamento: Francia, Bélgica..., op. cit., pág. 545.

34 Cfr. J. M. Porras, op. cit., pág. 103. 
premisas de una alianza entre el principio monárquico y la libertad republicana ${ }^{35}$.

De acuerdo con estas premisas, la disposición con la que se abre el Título relativo a "Los poderes" expresa de forma inequivoca la nueva concepción constitucional al respecto: "Todos los poderes emanan de la nación. Y son ejercidos de la forma establecida por la Constitución" (art. 25). Se trata, según L. Lacché, de la "norma-matriz" de la Constitución belga de $1831^{36}$, en la que quedan plasmados los principios de soberanía nacional y de supremacia constitucional. Es en este marco en el que hay que encuadrar la configuración de los poderes $y$, en particular, de la institución monárquica, cuyos propios rasgos configuradores responderán a criterios que difieren sustancialmente de los mantenidos hasta entonces.

En este sentido, el Rey experimentará una reubicación en el nuevo esquema de organización de los poderes, careciendo de poderes propios de origen extraconstitucional y debiendo ejercer los poderes que la Constitución expresamente le asigna ${ }^{37}$ en los términos previstos en ella: "El Rey no tiene otros poderes que los atribuidos de manera formal por la Constitución y las leyes establecidas en virtud de la propia Constitución" (art. 78). En este marco, al Rey se atribuye formalmente la titularidad del poder ejecutivo, precisando a continuación que éste será ejercido "en los términos regulados por la Constitución» (art. 29). A ello se dedican una serie de disposiciones constitucionales del Cap. II, relativas al Rey (particularmente arts. 64-78) en los que se plasma la limitación de los poderes reales por las Cámaras y la reserva de ley. Así, detenta la potestad reglamentaria "sin poder jamás suspender las leyes ni dispensar su ejecución" (art. 67); los Tratados de comercio que suscriba "sólo tienen efecto después de haber recibido el consentimiento de las Cámaras" (art. 68); acuña moneda "de acuerdo con la ley" (art. 74), confiere órdenes militares "observando lo prescrito en la ley" (art. 76); la dotación para la duración de cada reinado "la fija la ley" (art. 77), cerrándose este listado de atribuciones reales con la cláusula ya aludida del art. 78 que establece con carácter general la limitación de los poderes reales por la Constitución y las leyes que de acuerdo con ella se aprueben por las Cámaras.

35 L. LACCHÉ, op. cit., pág. 546.

36 L. LACCHÉ, op. cit., pág. 557.

37 Vid. al respecto P. WIGNY: Cours de Droit Constitutionnel, Bruylant, Bruselas, 1973, quien nos advierte de que el término "prerrogativas" es impropio para referirse a los poderes del Rey en Bélgica. 
Lo mismo cabe decir sobre las relaciones del Rey con las Cámaras, que también son objeto de una regulación constitucional en la que puede apreciarse una orientación reequilibradora a favor de éstas de signo tendencialmente parlamentario. Es significativo, como observa $L$. Lacché, que las disposiciones relativas a las Cámaras parlamentarias precedan a las referidas a las prerrogativas reales ${ }^{38}$. Hay que reseñar, en lo que concierne a las Cámaras, la configuración de un Parlamento bicameral, si bien se trata de un bicameralismo de signo distinto al conocido hasta entonces en Europa, en el que la Cámara Alta o el Senado no tendrán carácter aristocrático sino electivo, más próximo al modelo americano que a los europeos de la época.

Una mención especial merece la constitucionalización expresa del principio de responsabilidad ministerial (art. 63). Si bien se trataba de una práctica que ya venía dándose de facto en gran Bretaña y que habia tenido reflejo en la Charte orleanista (art. 12), su introducción en el nuevo marco constitucional belga va a resultar decisiva para el desarrollo del proceso de parlamentarización de la Monarquía. A diferencia de Francia, donde este proceso quedó interrumpido en 1848 (y de Gran Bretaña, donde carecía de formalización constitucional), la continuidad del texto constitucional belga permitirá el progresivo asentamiento de la forma de gobierno parlamentaria. La referencia a la responsabilidad ministerial ha de ser completada con otras disposiciones constitucionales que prevén el control parlamentario del Gobierno, bien mediante comisiones de investigación (art. 40) o mediante el requerimiento de la presencia de los Ministros en la Cámara(art. 88); a ello hay que añadir la regulación más pormenorizada, a través de los reglamentos de las Cámaras, de las diversas modalidades de control parlamentario 39 .

En definitiva, nos hallamos ante una configuración constitucional de la Monarquía que incide de forma determinante sobre los poderes del monarca y sobre sus relaciones con otros poderes (fundamentalmente las Cámaras), en ambos casos objeto de delimitación y de regulación conforme a los nuevos criterios constitucionales. De acuerdo con ellos, la Monarquía, a diferencia de cómo se había venido conformando hasta entonces, pasa a configurarse como un poder

38 Op. cit., pág. 549.

39 Según J. M. Porras: Principio democrático y función regia..., op. cit., pág. 107 , la forma de concebir y articular la responsabilidad ministerial constituye la principal aportación de la Constitución belga al constitucionalismo europeo de la época. 
constituido y como una forma de gobierno de signo tendencialmente parlamentario.

Es preciso reseñar, para finalizar, la importante novedad que supone, en el contexto constitucional europeo de la época, la introducción del principio de rigidez constitucional y su plasmación jurídica a través de un procedimiento específico para efectuar la revisión constitucional ${ }^{40}$. En este sentido, a iniciativa del poder legislativo, y una vez disueltas las Cámaras tras la declaración de revisión, unas nuevas Cámaras se pronunciarán, de acuerdo con el Rey, sobre los términos de la reforma constitucional, exigiéndose para ello un quórum especial de presencia ( $2 / 3$ de los miembros de cada Cámara) y una mayoría cualificada, también de $2 / 3$ en cada Cámara (art. 131). Más allá de los aspectos meramente procedimentales de la revisión constitucional, es ésta una cuestión que afecta a la propia concepción de la Constitución; en particular por lo que se refiere al principio de primacía constitucional, que no puede ser desvinculado del de rigidez constitucional. E incluso, como observa Loewenstein, es posible deducir a partir de la forma de contemplar la revisión constitucional, el carácter del régimen político ${ }^{41}$.

Tales consideraciones tienen especial aplicación en el constitucionalismo europeo del siglo XIX, que no se ocupará de recoger en sus textos los principios de supremacía y de rigidez constitucionales, a diferencia del americano, donde hallaron plasmación constitucional desde el principio ${ }^{42}$. La Constitución belga sí lo hará, recuperando este elemento característico del primer constitucionalismo (Constitución francesa de 1791 y, entre nosotros, Constitución de 1812), aportando un ingrediente innovador al constitucionalismo europeo de la época (en particular, en relación con la Charte orleanista de 1830) y anticipándose a lo que luego será aceptado de forma generalizada en posteriores textos constitucionales europeos (entre ellos, nuestra Constitución de 1869, como veremos en su momento).

40 Sobre la revisión constitucional, cuestión que en Bélgica ha tenido especial relevancia recientemente debido a las profundas reformas constitucionales realizadas entre 1970 y 1993, vid. P. WIGNY: La troisième revision de la Constitution, Bruylant, Bruselas, 1972, págs. 49 y ss.; asimismo, R. SENELLE: La Reforme de l'État belge, op. cit., págs. 40 y ss. 170 y ss.

41 K. Loewenstein: Teoría de la Constitución, Ariel, Barcelona, 1976, págs.

42 Cfr. P. DE VEGA, op. cit., págs. 38 y 42. 


\section{LA CONSTITUCIÓN DE 1869 Y EL INFLUJO DEL MODELO CONSTITUCIONAL BELGA DE 1831}

\section{El influjo generalizado del modelo belga en Europa en el siglo XIX y su repercusión en nuestro constitucionalismo histórico: la nonata de 1856}

Las características especiales que presenta la Constitución belga de 1831 en el contexto constitucional de la Europa de mediados del siglo XIX (1830-1870) explica el influjo que va a ejercer sobre otros países; en especial cuando en alguno de ellos se abra un proceso constituyente, a la búsqueda de una nueva configuración de su modelo institucional, o se acometa una reforma importante del sistema político. La Constitución belga apareció en este período como un referente ineludible ya que, como hemos visto, constituye una síntesis que integra elementos de las experiencias constitucionales de la época, tales como la Charte orleanista de 1830, sin duda su precedente más próximo; pero también las Cartas otorgadas de la Restauración, tanto la francesa de 1814 como la Ley fundamental neerlandesa (Grondwet) de 1815; del primer constitucionalismo revolucionario (Constitución francesa de 1791); e incluso, en particular en lo concerniente a los derechos y libertades, de la Constitución americana de $1787^{43}$.

Junto a esta sintesis de experiencias constitucionales de la época, otro de los rasgos distintivos de la Constitución belga va a ser la formalización que hace, en un texto codificado y articulado, del referente más claro de parlamentarización de la Monarquía en ese momento, sin duda alguna el británico. Hay que tener presente que durante todo el siglo XIX (y también después en muchos paises, entre ellos España) el proceso de parlamentarización de la Monarquía es una cuestión clave en la configuración del sistema político ${ }^{44}$. En este sentido, la contribución que supone el texto constitucional belga a la formalización de los rasgos característicos de la Monarquia en proceso de parlamentarización va resultar determinante, lo que explica también la proyección exterior que tuvo en su momento el texto constitucional que nos ocupa.

43 Cfr. J. GILISSEN: La Constitution belge de 1831, op. cit.

44 J. M. PorRas, en la obra ya reseñada Principio democrático y función regia..., proporciona una visión sintética de este proceso en la Europa del siglo XIX, con referencias, además de a Bélgica y a España, a otros paises muy significativos como Gran Bretaña, Francia y países escandinavos. 
Por otra parte, la obra del constituyente belga de 1831, además de hacer una síntesis de las principales experiencias constitucionales de la época ${ }^{45}$ y de formalizar en un texto codificado la orientación tendencialmente parlamentarizadora de la Monarquía, contribuirá decisivamente a abrir un nuevo ciclo constitucional tras el período de la Restauración. El constitucionalismo liberal que va a empezar a desarrollarse en Europa a partir de la década de los treinta del siglo XIX es deudor en buena medida de las aportaciones innovadoras de signo tendencialmente parlamentario y democratizador que introduce el texto constitucional belga de 1831 .

Teniendo en cuenta la concurrencia de estas características, que singularizan la experiencia constitucional belga de 1831 en el contexto constitucional de la época, no es de extrañar el influjo que ejercerá más allá de sus propias fronteras. A ello contribuirá también la gran estabilidad constitucional belga ${ }^{46}$, que contrasta fuertemente con la discontinuidad y la agitación constitucional de otros países que podían haber cumplido un papel referencial; particularmente Francia, donde se suceden los cambios a la búsqueda de la Constitución «inencontrable" (Charte octroyée de 1814, Charte orleanista de 1830, Constitución republicana de 1848 , Constitución imperial de $1852 \ldots$... No es posible tampoco hallar ningún otro modelo de referencia en la Europa de la época, anclada en la herencia de la Restauración y cuyo proceso de parlamentarización de sus respectivas Monarquías (Suecia, Noruega, Dinamarca, Países Bajos, Prusia, Austria, Cerdeña y Piamonte...) se encuentra en un estadio de desarrollo mucho menos evolucionado; será precisamente el influjo del referente belga a partir de 1831 uno de los factores que harán posible su evolución en una orientación de signo tendencialmente parlamentario.

La influencia de la Constitución belga durante las décadas siguientes, a mediados del siglo XIX, se extenderá a buena parte de

45 Según J. VARELA, la principal característica desde el punto de vista histórico-constitucional del texto belga de 1831 reside en haber acogido las dos tradiciones constitucionales europeas más relevantes: la británica y la francesa. Vid. su estudio introductorio "Las cuatro etapas de la Historia constitucional comparadan, en Textos básicos de la Historia constitucional comparada, C.E.C., Madrid, 1998, pág. XXVI.

46 Tan sólo dos leves reformas constitucionales, en 1893 y 1921, se realizaron en casi siglo y medio (1831-1970), lo que ha hecho de la estabilidad constitucional uno de los rasgos característicos del modelo belga, subrayado por todos los comentaristas. Vid. al respecto, F. DeLPERÉE: Le Droit Constitutionnel de la Belgique, Bruylant, Bruselas, 2000, págs. 63 y ss. 
Europa, representando, según Biscaretti, «el modelo para toda una amplia serie de nuevas o renovadas Monarquías"; tal es el caso de las reformas constitucionales de 1848 en los Paises Bajos y de la Constitución danesa de 1849; asimismo, del Estatuto albertino de 1848, cuya vigencia se prolongará a lo largo de un siglo en Italia, y de la Constitución prusiana de 1848-50, que a su vez inspiró la de Japón de 1889. $E$ incluso en un área tan lejana geográficamente ( $y$ políticamente) como la península balcánica, donde también sirvió como modelo de referencia para algunos de los nuevos Estados que iban surgiendo como consecuencia del proceso de desmembración del imperio otomano (Grecia, 1864; Rumania, 1866; Bulgaria, 1881)47.

No podían escapar al influjo generalizado de la Constitución belga en el constitucionalismo europeo de mediados del siglo XIX nuestros propios textos constitucionales, en los que ya desde 1837 puede empezar a apreciarse su influencia48; en especial, por lo que se refiere a los primeros intentos de introducir elementos de parlamentarización de la Monarquía. Si bien esta tentativa inicial va a verse obstaculizada por nuestra inestabilidad constitucional, y más concretamente, en este período, por el giro que supone la Constitución de 1845 , ello no podrá impedir que las tendencias de signo parlamentario vuelvan a reaparecer cada vez que se abra una coyuntura de cambio político. Tal es el caso del bienio progresista (1854-56), a pesar del frustrado proceso constituyente de la nonata de 1856, y lo será de forma más clara en la coyuntura revolucionaria de la gloriosa de 1868 , que dará lugar al constitucionalismo democrático del sexenio.

Por lo que se refiere a la nonata de 1856, el desarrollo del debate constituyente en las Cortes es sumamente revelador de la influencia que tuvieron en ella algunas de las constituciones extranjeras de la época; y entre ellas, de forma especial, la belga. Así, la Comisión dictaminadora, a través del diputado Lafuente, manifestaba que ula Comisión ha tomado lo que le ha parecido mejor de las constituciones de países que se rigen por gobiernos análogos al nuestron. Por su parte, Ríos Rosas, en nombre de la mayoría parlamentaria, afirmaba en el curso del debate constituyente que "las innovaciones introducidas en la Constitución de 1837 no son origináles; han sido tomadas de la Constitución belga y de la republicana [francesa] de 1848». Finalmen-

47 Cfr. B. MiRKINE-GUeTZEVITCH: Les Constitutions européennes, PUF, París, 1951, pág. 26.

48 Vid. A. Colomer: El sistema político de la Constitución española de 1837, Congreso de los Diputados, Madrid, 1989, pág. 656. 
te, J. de Arriaga, miembro de la minoría parlamentaria, justificaba su posición contraria al proyecto constitucional por su tendencia extranjerizante: «porque en vez de hacer una Constitución española estamos haciendo una Constitución extranjera», concluyendo que "cuando no copiamos de Francia, copiamos de Bélgica o de Inglaterra» 49 .

Las citas transcritas son suficientemente expresivas de la influencia que ejercieron en el constituyente del bienio progresista los modelos constitucionales europeos más conocidos de la época: el francés $(1830,1848)$, el británico y el belga; a los que habrá que añadir también el norteamericano, que a pesar de su lejanía geográfica ejercerá una influencia no despreciable en el constitucionalismo europeo de la época en general, de la que también fue partícipe el constitucionalismo histórico españo| ${ }^{50}$. La falta de vigencia efectiva de la nonata de 1856, nos permite eludir una referencia más amplia sobre la misma; no obstante, es preciso reseñar que contiene aportaciones innovadoras, inspiradas directamente en el texto belga, tales como el principio de soberanía nacional formulado en los mismos términos que la Constitución belga: "todos los poderes emanan de la nación" (art. 1 Const. 1856; art. 25 Const. belga); la constitucionalización del principio de tolerancia religiosa (art. art. 14 C. 1856; art. 14 C. B.); la regulación más precisa de las prerrogativas reales (arts. 52 y 53) y la ubicación, al igual que en la Constitución belga, del Título relativo al Monarca a continuación de los que se refieren a las Cortes; el establecimiento de un Tribunal de cuentas de origen parlamentario (art. 42, en relación con el 116 de la C. B.); y la acogida del principio de rigidez constitucional, articulando un procedimiento de reforma de la Constitución (arts. 87 y ss.) igual al previsto en la Constitución belga (art. 131 C. B. $)^{51}$.

\section{El movimiento de 1868 y el referente belga}

Pero más allá de la tentativa constitucional frustrada del bienio progresista, será en el constitucionalismo del sexenio donde las ten-

49 Citas transcritas de I. CASANOVA AgUILAR: Aproximación a la Constitución nonnata de 1856, Universidad de Murcia, 1985, págs. 116 y 118.

50 Como señala I. CASANOVA, op. cit., pág. 118, influyó de forma decisiva la difusión de la célebre obra de A. TocoueVILLE, La democracia en América, objeto de sucesivas ediciones en España en 1837, 1842, 1843 y 1852; esta última acompañada de un estudio de $\mathrm{E}$. CHAO, uno de los parlamentarios más activos en la Cortes.

51 Cfr. I. Casanova, op. cit. 
dencias constitucionales más avanzadas en la Europa de la época, $y$ particularmente la Constitución belga, tendrán ocasión de proyectar su influencia. Ello es debido a la concurrencia de varios factores, que pasamos a examinar a continuación y que conjuntamente van a propiciar que el referente belga sea determinante en el diseño del modelo constitucional del sexenio.

En primer lugar, los principales líderes que protagonizan la gloriosa de 1868, incluido el principal de ellos, el General Prim, han tenido estrechas relaciones con Bélgica, donde han vivido exiliados, lo que les permite conocer directamente el sistema politico y constitucional de ese país. No es casual que los principales hitos del proceso que desembocará finalmente en la revolución de septiembre de 1868 tengan como escenario el territorio belga. Así, el Pacto de Ostende lagosto de 1866), en el que las fuerzas de la oposición alcanzan un Acuerdo para el derrocamiento de la Monarquía isabelina, al que seguirá poco después la constitución de la Junta de Bruselas (junio de 1867), oncargada de coordinar las acciones de la alianza surgida en torno al Pacto de Ostende. Bélgica se convierte asi, a mediados del siglo XIX, en el centro de operaciones del movimiento opositor español, lo que lógicamente tendrá su repercusión sobre algunos de sus principales lideres, que no serán ajenos al ambiente político que vive Bélgica en ese momento ${ }^{52}$.

Otro de los factores a tener en cuenta era la composición del movimiento que da lugar a la coyuntura de 1868. Al igual que en Bélgica en 1830, donde la alianza entre católicos y liberales dará lugar al cambio político de 1830-31, del que la Constitución levantará acta, los sucesos de 1868 en España son también el resultado de una amplia alianza cívica que agrupa a la casi totalidad de los sectores sociales y fuerzas políticas - Unión Liberal, progresistas, demócratas - con el objetivo común de un cambio de régimen. La consolidación de este cambio, a través del establecimiento de un nuevo marco político y constitucional, expresión de la nueva alianza social y política, tendrá en la experiencia belga un referente que el constituyente de 1869 no podrá eludir.

El cambio político de 1868 no estaba planteado por sus protagonistas como un mero cambio de gobierno, ni fue tampoco el típico

52 Sobre este período, vid. M. ARTOLA: La burguesía revolucionaria, Alianza, Madrid, 1977; en particular, el pasaje dedicado a la revolución de 1868, págs. 363 y ss. 
pronunciamiento militar. Se trataba, a diferencia de ocasiones anteriores, de una auténtica ruptura política con el régimen existente hasta el momento ${ }^{53}$, encarnado por la Monarquía isabelina. Ello hacia necesario plantearse la reorganización institucional del sistema político en su conjunto sobre nuevas bases; muy en particular, por lo que se refiere al papel que la Monarquía habrá de jugar en lo sucesivo. De acuerdo con estas premisas, que eran las que se daban en la coyuntura de 1868, no cabe duda de que el modelo belga, donde se establece una Monarquía ex novo en 1831, dotándola desde el primer momento de perfiles tendencialmente parlamentarios, era el más idóneo para abordar la reconfiguración radical de la institución monárquica, tal $y$ como pretendían los principales líderes de 1868.

Existían, además, otras cuestiones pendientes en 1868 como era la democratización institucional, terreno en el que la Constitución belga también aporta elementos de referencia, tanto de carácter general como en aspectos concretos tales como la extensión al Senado del carácter electivo, a diferencia de lo que ocurría en otras Cámaras similares de la época. Hay que tener en cuenta que el radicalismo democrático era uno de los componentes esenciales de la revolución de 1868 , que necesariamente iba a verse reflejado en términos constitucionales en la configuración de las instituciones. Por último, existía la cuestión religiosa, que en España revestía especial trascendencia ${ }^{54}$ y que en Bélgica, donde también ha tenido una importante incidencia en el plano político, era objeto de un tratamiento constitucional específico sobre la base de la libertad de cultos y de la separación Iglesia-Estado que, como veremos, servirá también de referente al constituyente de 1869.

La concurrencia de los factores señalados inducirá al constituyente surgido de la revolución del 68 a tener presente la experiencia constitucional belga, tanto por las similitudes que podian observarse en algunos aspectos del proceso que habia dado lugar al cambio politico como por el ejemplo de estabilidad constitucional que, bajo la forma de una Monarquía tendencialmente parlamentaria, ofrecía Bélgica en ese momento. Ello se pondrá claramente de manifiesto en la confección del texto constituciónal de 1869, que establecía el nuevo marco político que regirá durante el sexenio.

53 Son ilustrativos al respecto los Manifiestos aprobados por las Juntas; vid. V. Bozal: Juntas revolucionarias, Manifiestos y Proclamas de 1868, Edicusa, Madrid, 1968.

54 Sobre este tema, vid. S. PETSCHEN: Iglesia-Estado, un cambio político. Las constituyentes de 1869, Taurus, 1974. 


\section{La estructura formal del texto constitucional de $\mathbf{1 8 6 9}$}

La primera característica sobre la que es preciso llamar la atención en el nuevo texto constitucional de 1869 (antes de entrar en el examen de su contenido) hace referencia a su estructura formal, que contrasta con la de todos los textos constitucionales anteriores desde 1812 $(1834,1837,1845)$, al tiempo que presenta una gran similitud con la Constitución belga de 1831. Así, salvo el Tít. I de ésta, referido al «Territorio y sus divisiones", cuestión de la que no se ocupa nuestra Constitución de 1869, el resto del texto constitucional reproduce, sin apenas variaciones, el esquema de aquella, siguiendo incluso el mismo orden y llegando a utilizar, en muchos casos, los mismos términos. Así, Tít. I: «De los españoles y sus derechos», idéntica a la expresión utilizada en la Constitución belga (Tít. II: "De los belgas y sus derechos") y sensiblemente diferente a la fórmula utilizada en las Constituciones precedentes de 1837 y 1845, que en el Título equivalente (Tít. I en ambos caso) se referían a "los españoles" omitiendo la referencia los derechos.

A continuación, ambos textos constitucionales (Constitución española de 1869 y belga de 1831; en adelante CE 1869 y CB 1831) pasan a regular la organización institucional del Estado, utilizando en el encabezamiento de los respectivos Títulos sobre esta materia términos similares: "De los poderes" (CB 1831) y "De los poderes públicos" (CE 1869). Hay que advertir que esta referencia a "los poderes" del Estado no existe en las constituciones precedentes de 1837 y 1845, ni tampoco en otros textos europeos de época, salvo en la Constitución republicana francesa de 1848 , que utiliza idéntica expresión que la española de 1869. No se trata de una mera cuestión semántica ni de estilo literario (como tampoco lo es la referencia expresa o no a "los derechos" a la que ya nos hemos referido anteriormente) sino que denotan una concepción constitucional distinta sobre la organización institucional del Estado, basada en el principio de división de poderes $^{55}$.

El esquema seguido por el constituyente de 1869 en la regulación de los poderes es coincidente con el de la Constitución belga de 1831. Asi, tras un pasaje inicial referido a los poderes en general (arts. 32-37 CE 1869; arts. 25-31 CB 1831), que en ambos casos se abre con 
una disposición en la que se afirma expresamente el principio de soberanía nacional, expresado en idénticos términos - «todos los poderes emanan de la nación»-, se pasa a regular, a continuación, cada uno de los poderes del Estado: el poder legislativo y las Cámaras parlamentarias, el Rey y los Ministros, y el poder judicial, completándose esta parte orgánica con una referencia a las instituciones provinciales y municipales. Si bien estas materias de carácter orgánico-institucional también eran reguladas en las constituciones precedentes de 1837 y 1845, su contenido, sin embargo, va a ser sensiblemente distinto como tendremos ocasión de comprobar en su momento.

Donde sí va a existir una diferencia importante, que además del contenido afecta a la estructura del texto constitucional, es en la existencia, tanto en la CE 1869 como en la CB 1831 de un Título específico, el último en ambos casos, (inexistente en los textos precedentes de 1837 y 1845, así como en otros textos extranjeros de la época), dedicado a la reforma constitucional. Se trata de un elemento estructural clave de la Constitución ${ }^{56}$, como es su rigidez, que va a tener acogida de forma expresa en el propio texto constitucional. Es preciso reseñar este dato, ya que la rigidez constitucional, que posteriormente será un elemento integrante de los textos constitucionales, no lo era a mediados del siglo $X I X$ en el constitucionalismo europeo de la época.

Interesa llamar la atención sobre la acusada coincidencia existente en la estructura formal de ambos textos constitucionales (CE 1869, CB 1831), que resulta más llamativa aún en contraste con nuestros textos precedentes de 1837 y 1845, así como también con otros textos constitucionales europeos de la época. No resulta aventurado deducir de esta coincidencia en la estructura y ordenación de ambos textos - derechos, poderes, rigidez - un claro influjo del modelo belga vigente desde 1831 en nuestro constituyente de 1869. Pero este influjo se va a hacer más patente si atendemos al contenido de ambos textos, donde pueden apreciarse también nexos comunes en el tratamiento constitucional que van a recibir tanto los derechos y libertades como la organización de los poderes del Estado.

56 Hasta el punto de que K.LOEWENSTEIN llega a afirmar que a partir de él se puede deducir el carácter del régimen político: Teoría de la Constitución, Ariel, Barcelona, 1976, especialmente el apartado dedicado a la reforma constitucional, págs. 170 y ss. 


\section{La reformulación constitucional de los derechos y libertades}

Uno de los rasgos más distintivos de la Constitución de 1869, tanto en relación con los textos constitucionales precedentes de 1837 y 1845 como con otros textos constitucionales europeos de la época, es el tratamiento que tienen en ella los derechos y libertades ${ }^{57}$. Ello no es sino la expresión del radicalismo liberal y democrático que inspiraba a los protagonistas de la Gloriosa de 1868 , muy alejados del doctrinarismo o del eclecticismo que había inspirado otras experiencias constitucionales precedentes, $y$ que hallará su plasmación con toda nitidez en la obra del constituyente de 1869.

Contrasta, en primer lugar, la extensión y amplitud con la que son tratados los derechos y libertades, tema al que se dedican las treinta $y$ un primeras disposiciones constitucionales del texto de 1869 , en comparación con las once que se dedicaban al mismo tema en los textos constitucionales precedentes de 1837 y 1845 (y asimismo en otros textos constitucionales extranjeros como la Charte orleanista: arts. 1-11). Aunque sólo sea en términos meramente cuantitativos, lo que en sí mismo no es determinante pero sí es un dato a tener en cuenta sobre la atención que este tema merece al constituyente, puede observarse una mayor proximidad con el tratamiento que esta cuestión recibe en el texto constitucional belga de 1831 (arts. 4-25); con el que, como se verá más adelante, podrán apreciarse también similitudes significativas de contenido.

Es preciso puntualizar, no obstante, que no es éste el terreno en el que más decisiva fue la influencia del texto constitucional belga de 1831, cuya proyección sobre el constitucionalismo del sexenio se dejó sentir de forma especial en la configuración del modelo institucional, y muy particularmente en su contribución a la parlamentarización de la Monarquía. A ello hay que añadir que durante las casi cuatro décadas transcurridas entre ambos textos (1831-1869), habían ido emergiendo nuevos derechos democráticos de participación política, asi como también se habían ido perfilando de forma más definida los derechos civiles clásicos, lo que tendrá su reflejo en el texto de $1869^{58}$. Así

57 Sobre este tema, tanto en nuestro constitucionalismo histórico como, en particular, en la Constitución de 1869, vid. F. TOMÁS Y VALIENTE: "Los derechos fundamentales en la historia del constitucionalismo español", en Obras completas, tomo III, págs. 2023 y 2034.

58 Cfr. B. Clavero: Manual de Historia constitucional de España, Alianza, Madrid, 1989; en particular, cap. VII, dedicado a la Constitución de 1869, Ap. "¿Qué son los derechos?», págs. 101 y ss. 
pues, éste no sólo será receptor de influencias exteriores, particularmente la belga, sino que, además, tendrá también aportaciones de interés al constitucionalismo democrático de la época.

Otro factor a tener en cuenta es la influencia que tuvo sobre el constitucionalismo del sexenio la Constitución USA, en particular en materia de derechos y libertades. Es preciso reseñar (ver supra) que esta influencia americana ya se dio también en su momento sobre el constituyente belga de 1831 en lo relativo a los derechos y libertades. Esta doble influencia de los dos textos constitucionales - el belga y el americano - más avanzados de la época en la materia, singularizan a nuestra Constitución de 1869 como uno de los documentos más emblemáticos del constitucionalismo democrático de XIX.

Así ha sido puesto de manifiesto en los comentarios doctrinales al respecto; en este sentido, Fernández Segado, al referirse al Tít. I ( $\mathrm{De}$ los españoles y sus derechos») afirma que "a lo largo de sus 31 artículos, recoge la más extensa y completa declaración de derechos individuales de los textos constitucionales promulgados hasta ese momento"; opinión compartida por Torres del Moral quien, además, llama la atención sobre el art. 29, "de genuino estilo condorcetiano", que amplía el ámbito de los derechos a cualquier otro no comprendido expresamente en su enumeración ${ }^{59}$. Por otra parte, no sólo se contemplan los derechos civiles clásicos propios del constitucionalismo liberal sino que, junto a ellos, va a hacer su aparición una nueva generación de derechos públicos y de participación política que confieren a esta declaración constitucional de derechos un carácter realmente innovador.

No es la finalidad de estas líneas hacer un análisis pormenorizado de esta extensa declaración de derechos, que necesariamente tendría que ser objeto de un trabajo monográfico dedicado exclusivamente al tema ${ }^{60}$. Tan sólo reseñar al respecto la mayor amplitud y concreción con que son contemplados los derechos civiles clásicos, que como observa J. Tomás Villarroya van a ser objeto de regulación constitucional directa con el fin de impedir su desnaturalización posterior a través de su regulación legal (o la falta de ésta), tal y como había ocu-

59 Vid. F. Fernández Segado: Constituciones históricas..., op. cit., pág. 299, y A. Torres del Moral: Constitucionalismo histórico español, Átomo Ed., Madrid, 1986, pág. 102.

60 Cfr. A. CARro: La Constitución española de 1869, op. cit; i en particular, las páginas dedicadas al comentario de los arts. 1-31; págs. 161-255. 
rrido en anteriores constituciones. Para ello, la propia Constitución preveía expresamente que «no se establecerá ni por la ley ni por las autoridades disposición alguna preventiva que se refiera al ejercicio de los derechos definidos en este Título" (art. 22), lo que constituye una importante novedad en la forma de concebir los derechos. Como también lo era, en este caso por lo que supone de concepción extensiva de los derechos, la cláusula constitucional que establecía que "la enumeración de los derechos consignados en este Título no implica la prohibición de cualquiera otro no consignado expresamente» (art. $29)^{61}$, con lo que se ampliaba considerablemente el ámbito de los derechos y las libertades constitucionales.

Junto a esta nueva concepción de los derechos en general, de carácter garantista y extensivo, es preciso referirse, a continuación, a la novedad que supone la constitucionalización de una serie de derechos democráticos, tales como el derecho de reunión (arts. 17 y 18), de asociación (arts. 17 y 19), de petición colectiva (arts. 17 y 20), que hacen su aparición por primera vez en nuestro ordenamiento constitucional ${ }^{62}$. Se trata de un grupo de derechos que, junto al de sufragio para todo uespañol que se halle en el pleno goce de sus derechos civiles" (art. 16), son claves para la democratización de la vida política y cuya recepción constitucional marca el tránsito al constitucionalismo democrático.

En relación con los mencionados derechos, es preciso reseñar que si bien suponen una novedad en nuestro constitucionalismo, se encontraban ya recogidos en algunos textos constitucionales europeos; el primero de ellos, el belga de 1831 en términos muy similares (arts. 19, 20 y 21), excepto por lo que se refiere al derecho al sufragio; y asimismo, en la Constitución republicana francesa de 1848 (art. 8). Nuestro constituyente de 1869 no fue ajeno al influjo de éstos, que sin duda constituyen el referente más claro del constitucionalismo democrático de la época en Europa y cuya conexión con el constitucionalismo del sexenio no debe pasar desapercibida.

Hay que hacer mención, asimismo, de la libertad de enseñanza, ignorada en los textos constitucionales precedentes de 1837 y 1845 y

61 Para un comentario específico sobre esta emblemática disposición constitucional de 1869 y la inspiración norteamericana sobre ella, vid. J. OLTRA: La influencia norteamericana en la Constitución española de 1869, op. cit., págs. 119 y ss.

62 Sobre la incorporación constitucional de estos derechos, vid. R. FLAQUER: "El derecho de asociación, reunión y manifestación", en Derechos y Constitución, AYER, $\mathrm{n} .^{\circ} 34,1999$, págs. 162 y ss. 
que será contemplada de forma expresa en el de 1869 (art. 24) ${ }^{63}$. También en este caso es posible detectar la influencia de los referidos textos constitucionales belga de 1831 (art. 17) y francés de 1848 (art. 9), tanto por la constitucionalización expresa de esta materia (no se alude a ella en la Charte orleanista de 1830), como por los términos en que se hace, con exclusión de cualquier ulicencia previa" (CE 1869) o "medida preventiva» (CB 1831). Se trata de un tema que, tanto por razones históricas como sociológicas, será especialmente polémico en Bélgica y en España.

Una mención especial merece la libertad religiosa y de culto, que va a tener un tratamiento distinto al que tenía en los textos constitucionales precedentes, donde sólo se hacía referencia a la religión católica (art. 11 de la Constitución de 1837 y de 1845); en la de 1869 se proporciona, por primera vez, cobertura constitucional a la libertad de cultos ${ }^{64}$, si bien de forma muy tímida, distinguiendo entre "el ejercicio de otros cultos [distinto del católico] por los extranjeros residentes en España» y "los españoles que profesaren otra religión que la católica», obligándose, en todo caso a "mantener el culto y los ministros de la religión católica» (art. 21). Aunque esta forma de tratar constitucionalmente la libertad religiosa dista bastante de la que esta cuestión recibía en la Constitución belga de 1831 (arts. 14, 15 y 16) y en la Constitución republicana francesa de 1848 (art. 7), en las que se aborda con mayor claridad el tema de la libertad religiosa y, sobre todo, la separación Iglesia-Estado, no cabe duda que ambos textos influyeron en el debate constituyente de 1869 sobre la materia, ayudando a abrir brecha en el monolitismo religioso existente. Hay que añadir, además, que esta cuestión, que suscitó la polémica más aguda en el debate constituyente, experimentó una reformulación constitucional poco después, sobre la base de una separación más tajante Iglesia-Estado, tal y como se recogía en el proyecto constitucional republicano de 1873 (arts. 34 y 35 ).

Una observación final es preciso hacer en relación con una cuestión que tanto en Bélgica como en España irá cobrando con el tiempo un protagonismo creciente, como es la cuestión lingüística. Mientras la Constitución belga de 1831 dedica una disposición constitucional específica a este tema (art. 23), estableciendo el uso facultativo de las

63 Vid. R. PRIETO: «Instrucción: derecho a saber y derecho a enseñar», en Derechos y Constitución, op. cit., págs. 145 y ss.

64 Vid. M. J. CABrera: "La libertad religiosa", en Derechos y Constitución, op. cit., págs. 107 y ss. 
lenguas y previendo su regulación mediante ley, la Constitución española de 1869, que en tantos aspectos recibió el influjo de aquella, no contiene referencia alguna a este tema. A diferencia de Bélgica, donde la cuestión lingüistica tuvo proyección constitucional desde el primer momento, en España habrá que esperar hasta que se produzca el primer intento de reorganización autonómica del Estado con la Constitución republicana de 1931, para que aparezcan las primeras referencias constitucionales sobre esta cuestión 65 .

\section{La reconfiguración institucional de los poderes y la parlamentarización de la Monarquía}

Junto a la declaración de derechos y libertades, la configuración constitucional de los poderes del Estado va a ser el otro terreno en el que se van a poner de manifiesto las aportaciones innovadoras de la Constitución de 1869 en relación con los textos constitucionales precedentes de 1837 y 1845; y asimismo, donde mejor puede apreciarse la influencia del constitucionalismo europeo de la época sobre el modelo constitucional del sexenio. Si bien, en líneas generales, puede hablarse de una triple influencia - británica, francesa y belga-, la singularidad del modelo británico y la inestabilidad constitucional francesa (los textos de 1830 y 1848 carecieron de continuidad) hace que sea el modelo belga el que aparezca como referente principal; sobre todo por su contribución a la parlamentarización de la Monarquía, que en ese momento era una de las cuestiones claves que incidia de lleno en la articulación institucional de los poderes del Estado66.

Como ya se indicó en su momento, al referirnos a la estructura del texto constitucional, la Constitución de 1869, al igual que la belga de 1831 ( $y$ que la francesa de 1848), y a diferencia de todas las demás, dedica unas disposiciones previas a "los poderes» del Estado, en general, antes de pasar a regular cada uno de los órganos legislativo, ejecutivo y judicial. A pesar de que esta forma de tratamiento constitu-

65 El art. 50 de la Constitución de la II República de 1931 contiene la primera referencia constitucional en materia ligüistica al prever que "las regiones autónomas podrán organizar la enseñanza en sus lenguas respectivas, de acuer* do con las facultades que se concedan en sus Estatutos».

66 Cfr. al respecto J. M. PORRAs: Principio democrático y función regia..., op. cit., las páginas dedicadas a la Constitución de 1869 en el proceso de parlamentarización de la Monarquía; págs. 129-135. 
cional de los poderes y de los órganos que los ejercen ha sido objeto de crítica por parte de algunos comentaristas, por entender que es superflua y reiterativa ${ }^{67}$, hay que decir que en este pasaje inicial referido a los poderes se contienen algunos de los pronunciamientos esenciales del constituyente.

En primer lugar, la afirmación del principio de soberanía nacional, que desde 1812 había sido una de las cuestiones más controvertidas y polémicas. Si bien en el preámbulo de la Constitución de 1837, como también en el de la de 1869 (no así en el de la de 1845) había una referencia a la soberanía nacional 68 , su ubicación en el articulado del texto constitucional, abriendo el Título relativo a "los poderes públicos", le otorga pleno significado como fundamento de los poderes y de la organización institucional del Estado. Se trata de una concepción nueva, propia del constitucionalismo democrático, que difiere de la que se había venido manteniendo hasta entonces bajo la influencia de los postulados doctrinarios.

Esta afirmación del principio de soberanía nacional se verá reforzada, además, por la puntualización subsiguiente referente a «la nación, de la cual emanan todos los poderes" (art. 32). En este caso, el texto reproduce literalmente la fórmula empleada en la Constitución belga: "Todos los poderes emanan de la nación» (art. 25 CB 1831); así como también de la Constitución republicana francesa de 1848: "Todos los poderes, cualesquiera que sean, emanan del pueblo" (art. 18). Se trata, en todos los casos, de una formulación típica del constitucionalismo democrático, cuya incorporación a nuestro acervo constitucional se produce gracias al influjo ejercido sobre el constituyente de 1869 por los referidos precedentes constitucionales, belga de 1831 y francés de 1848.

En estrecha relación con la fundamentación democrática de los poderes está su articulación sobre la base del principio de separación de poderes ${ }^{69}$, cuestión de la que se ocupa, a continuación, nuestra Constitución de 1869, reproduciendo también, a este respecto, el mismo esquema seguido por la Constitución belga de 1831; y en menor

67 A. Carro: La Constitución española de 1869, op. cit., págs. 147-148.

68 Sobre los preámbulos de nuestras Constituciones históricas, y en particular de la 1869, vid. J. TAJADURA: El preámbulo constitucional, Comares, Granada, 1997, págs. 128 y ss.

69 Sobre este tema cfr. B. Clavero: Manual de Historia constitucional de España, op. cit.; en particular, en cap. VIl, dedicado a la Constitución de 1869, el Apartado "¿Qué es la división de poderes?», págs. 107-114. 
medida, la Constitución republicana francesa de 1848 , que se limitaba a sentar el principio separación de poderes (art. 19) sin hacer después ninguna referencia específica a cada uno de ellos, tal y como se hace en el texto belga y en el español. Aunque el esquema seguido en estos dos últimos es el mismo, puede apreciarse una mayor elaboración en nuestro texto de 1869 en la definición de los poderes, en particular del legislativo y ejecutivo. Así, a diferencia del texto belga, en el que «el poder legislativo es ejercido conjuntamente por el Rey, la Cámara de Representantes y el Senado" (art. 26), aludiendo seguidamente a "las tres ramas del poder legislativo" (art. 27), la que no es sino el reflejo de la tradicional fórmula británica "the King in The Parliament" antes de la consolidación de la Monarquía parlamentaria, nuestro texto constitucional tiene una formulación más matizada, atribuyendo «la potestad de hacer las leyes" a las Cortes y reservando al Rey la sanción y la promulgación de las mismas (art. 34). Asimismo, y por lo que se refiere al poder ejecutivo, si bien en ambos casos se le atribuye expresamente al Rey, "de acuerdo con la Constitución" según el texto belga (art. 29), precisándose en el texto español que "el Rey lo ejercerá por medio de sus Ministros" (art. 35).

Una novedad importante en la Constitución de 1869 va a ser la referencia a los municipios y provincias; no tanto por la referencia en sí misma, que ya existía en los textos constitucionales precedentes de 1837 y 1845 ( $y$ también en el de 1812) sino por la forma en que se hace $^{70}$. Dos rasgos es preciso reseñar al respecto; ambos coincidentes con el tratamiento que a los entes provinciales y municipales se da en la Constitución belga, cuya influencia también se va a dejar sentir en este terreno. En primer lugar, su ubicación en el texto constitucional, coincidente en ambos casos, en el mismo Título relativo a "los poderes" con carácter general, a continuación de las disposiciones relativas a los poderes legislativo, ejecutivo y judicial; ello otorga a los entes territoriales, municipales y provinciales, un lugar propio en el esquema organizativo de los poderes, dando cabida a criterios de orden territorial. Pero además de este rasgo común, ambos textos constitucionales coinciden en introducir la noción de "intereses» propios - "peculiares" en el caso español, "exclusivos» en el belga- referidos al ámbito local, que han de ser gestionados por los Ayuntamientos y Diputaciones (Consejos municipales y provinciales en

70 Sobre esta cuestión, y sobre las leyes provincial y municipal de Octubre de 1868, vid. R. VILLENA: "La crisis del Estado centralista y la Administración territorialı, en El sexenio democrático, AYER, n. ${ }^{\circ} 44,2001$, págs. 86 y ss. 
Bélgica). La sorprendente similitud, tanto por su ubicación como por su contenido, entre ambas disposiciones constitucionales (art. $35 \mathrm{CE}$ 1869; art. 31 CB 1831) viene a ilustrar una vez más la relación existente entre nuestra Constitución de 1869 y la belga de 1831.

\subsection{Las Cámaras parlamentarias}

La Constitución de 1869 mantiene el modelo bicameral ya existente desde 1837 (y modificado en 1845). Fue ésta una cuestión que se suscitó en el debate constituyente de 1869 , en el que a pesar de no faltar quienes se mostraban partidarios de la opción monocameral, más acorde en principio con el radicalismo democrático de la revolución de 1868, se optó finalmente por el mantenimiento del bicameralismo. Ahora bien, es preciso advertir que se trata de un bicameralismo que presenta características distintas al que diseñaban las Constituciones de 1837 y 1845, así como también la Charte orleanista de 1830, y en el que se deja sentir una vez más la influencia de otros modelos constitucionales extranjeros, particularmente el americano y el belga.

Los argumentos utilizados en el debate constituyente para justificar la dualidad de Cámaras revelan la nueva concepción sobre el bicameralismo; ya no se trata de justificar una segunda Cámara de carácter aristocrático sino de combinar la representación de los intereses generales con los locales. Así lo manifestaba el diputado demócrata y miembro de la Comisión constitucional, Moret, para quien «si la idea de Cámara única es la de la representación de la totalidad del país, la idea de las dos Cámaras manifiesta la representación del Municipio y de la Provincian" 71.

Establecido el carácter bicameral de las Cortes, con las características señaladas, la regulación que el constituyente de 1869 hace del poder legislativo (Tít. III, arts. 38-66) difiere sensiblemente de la que se hacía en los precedentes textos constitucionales de 1837 y 1845. Además de los nuevos elementos que introduce el texto de 1869 (a los que nos referiremos a continuación), éste va a reflejar un posición "más parlamentaria», dedicando atención preferente a la regulación

71 Cit. por J. Tomás Villarroya: Breve historia del constitucionalismo español, op. cit., pág. 89. Para un estudio más amplio del Senado, vid. BERTELSEN REPETTO: El Senado en España, I.E.A., Madrid, 1974. 
de ambas Cámaras conjuntamente, como poder legislativo, pasando a continuación a ocuparse de cada una de ellas en particular. Hay que observar que este esquema en el tratamiento constitucional de la Cámaras parlamentarias coincide plenamente con el que sigue el texto constitucional belga de 1831 , lo que pone de manifiesto una vez más la influencia que éste ejerció sobre el constituyente de 1869.

La lectura de las disposiciones constitucionales de ambos textos sobre las Cámaras parlamentarias nos permite detectar numerosas coincidencias entre ellos, a veces expresadas incluso en los mismos términos. Hay que advertir que algunas de estas coincidencias son compartidas también con textos precedentes, principalmente el de 1837; ello es debido a que éste, a su vez, fue también receptor, en su dia, de la influencia de la Constitución belga de 1831, asi como también de la Charte orleanista de $1830^{72}$ (ver supra) que influyó sobre ambas (Constitución belga de 1831 y española de 1837). Así, es posible detectar en los referidos textos disposiciones similares relativas a la publicidad de las sesiones de las Cámaras, aunque admitiendo la posibilidad de excepciones (art. 33 CB 1831; art. 35 CE 1837; art. 48 CE 1869); la exigencia de un quórum de presencia en las Cámaras de la mitad más uno para poder votar las leyes (art. 38 CB 1831; art. 38 CE 1837; art. 51 CE 1869); la iniciativa legislativa compartida por el Rey y las Cámaras (art. 27 CB 1831; art. 36 CE 1837; art. 54 CE 1869); la capacidad de autoorganización de las Cámaras (arts. 37 y 46 CB 1831; arts. 29 y 30 CE 1837; art. 45 CE 1869); o la constitucionalización de la inmunidad e inviolabilidad parlamentarias (arts. 44 y 45 CB 1831; arts. 41 y 42 CE 1837; arts. 56 y 57 CE 1869).

Junto a ellas se puede apreciar también la aparición de nuevas disposiciones constitucionales que sólo encuentran correspondencia en la Constitución belga de 1831. Cabe reseñar entre ellas, la constitucionalización del mandato representativo (art. 32 CB 1831; art. 40 CE 1869) con la consiguiente exclusión del mandato imperativo (art. $41 \mathrm{CE}$ 1869); la exigencia de votación artículo por artículo de los proyectos de ley (art. 41 CB 1831; art. 52 CE 1869); la prohibición de presentar peticiones personales a las Cámaras (art. 43 CB 1831; art. 55 CE 1869); la incompatibilidad del cargo parlamentario con cualquier función vinculada al gobierno, salvo la ministerial (art. $36 \mathrm{CB} 1831$; art. $59 \mathrm{CE}$ 1869); la preceptiva intervención de las Cámaras para que el Rey pue-

72 Vid. A. Colomer: El sistema político de la Constitución española de 1837, Congreso de los Diputados, Madrid, 1989, págs. 653 y ss. 
da indultar a los Ministros (art. 91 CB 1831; art. 90 CE 1869); o el derecho de interpelación de los parlamentarios sobre los Ministros (art. 53 CE 1869, en relación con el art. 43 de la CB).

Una de las novedades más destacables del nuevo sistema institucional diseñado por la Constitución de 1869 es la reconfiguración del Senado, que por primera vez va a tener carácter electivo. Se trata de una importante innovación no sólo en relación con nuestro constitucionalismo histórico (en 1812 no había Senado; en 1834, 1837 y 1845 no tiene carácter electivo) sino también en relación con el constitucionalismo comparado de la época, en el que o bien aparece con carácter aristocrático no electivo - Chambre des Pairs francesa según la Charte de 1830 , Cámara de los Lores británica - o bien la suprime ${ }^{73}$, como es el caso de la II República francesa en 1848. Tan sólo la Constitución belga de 1831 preveía, en la Europa de la época, un Senado de carácter electivo, que fue precisamente el modelo adoptado por el constituyente de 1869 (así como también posteriormente en el proyecto constitucional de 1873, si bien en este último caso de carácter federal).

En el esquema diseñado por el constituyente de 1869, la composición y el procedimiento de elección del Senado respondía a criterios distintos de los del Congreso; en vez de elección directa, como los diputados, era indirecta de segundo grado, formándose un colegio electoral de ámbito provincial a partir de los distritos municipales que era el encargado de elegir a los senadores de cada provincia. Esta configuración del Senado atendiendo a criterios de representación territorial paritaria (cuatro senadores por cada provincia, independientemente de su población) ha conducido a algunos comentaristas a buscar semejanzas con el Senado americano. Creemos, sin embargo, que se trata de una apreciación forzada ${ }^{74}$ ya que ni este Senado tenia carácter federal ni las provincias eran equiparables a los Estados miembros de la Federación. Será en el proyecto constitucional republicano de 1873 en el que sí puede hablarse de un Senado federal inspirado en el modelo americano.

Mayores semejanzas pueden hallarse, a nuestro juicio, entre la configuración del Senado en nuestra Constitución de 1869 y la belga de 1831. En primer lugar, como ya se ha señalado, por la condición de miembros electos de los senadores teniendo en cuenta criterios de

73 Sobre a evolución histórica de la «Segunda Cámara" en Europa, vid. J. Mastias y J. Grange: Les Secondes Chambres du Parlament en Europe occidentale, Económica, París, 1987, págs. 39 y ss.

74 Vid. en este sentido, J. TOMÁs VillarRoya, op. cit., pág. 90. 
ámbito territorial provincial (si bien en el caso belga no existía paridad en el número de senadores por provincia). Asimismo, por la introducción de mecanismos de elección indirecta (parcialmente en el caso belga) asi como por la participación de las instancias representativas provinciales - Consejos provinciales en Bélgica, Diputaciones provinciales en España - en la elección de los senadores. Por último, por el carácter selectivo que tenía la elección de los senadores, ya que se exigía una serie de condiciones que necesariamente habían de cumplir quienes aspirasen a tal cargo representativo; fundamentalmente la pertenencia determinadas categorías profesionales vinculadas a la vida pública - ministros, parlamentarios, magistrados, alta administración, cargos militares, jerarquias eclesiásticas (en el caso español) etc. - o privada, que el propio texto constitucional se ocupaba de precisar (art. 56 CB 1831 , art. 62 CE 1869) en términos muy similares. Es ilustrativo al respecto que hasta la edad para poder ser senador fuese fijada en ambos textos de forma coincidente (40 años).

Por lo que se refiere al Congreso, la Constitución de 1869 se limita a una lacónica referencia sobre su forma de elección - «un diputado al menos por cada 40.000 almas de población" - remitiendo a la ley electoral para mayores precisiones ${ }^{75}$, tema que en la Constitución belga es tratado con mayor amplitud (arts. 47-52). Sí hay coincidencia, sin embargo, con ésta en las condiciones exigidas parar ser diputado, en particular por lo que se refiere a la previsión de ugozar de todos los derechos civiles" (art. 66 CE 1869; art. 50 CB 1831); interesa reseñar que esta formulación, coincidente con la que el art. 16 establece para poder ser elector, excluye cualquier otra exigencia en base a criterios censitarios o capacitarios, como había sido usual hasta ese momento, para ejercer la representación como diputado.

Tanto las disposiciones relativas a la elección del Congreso como del Senado, a las que nos hemos referido en los párrafos precedentes, deben ponerse en relación con el art. 16 del texto de 1869, que constitucionalizaba por primera vez el sufragio universal (masculino) ${ }^{76}$,

75 Ley electoral de 23 de junio de 1870 . El texto de esta ley (quince primeros artículos) puede verse en D. SEVILLA ANDRÉs: Constituciones y otras leyes..., op. cit., págs. 545 y ss.

76 Antes de aprobarse la Constitución (junio de 1869) ya se había establecido el sufragio universal (masculino) mediante Decreto aprobado por el Gobierno provisional (9 de noviembre de 1868). El texto de este decreto, con el que se realizaron las elecciones a las Cortes constituyentes de 1869 , puede verse en $D$. SeVILLA ANDrés: Constituciones y otras leyes..., op. cit., págs. 511 y ss. 
contribuyendo asi de forma decisiva a la democratización de las instituciones, particularmente de las Cámaras parlamentarias como máxima instancia representativa. Se trata, sin duda, de uno de los rasgos más distintivos del constitucionalismo del sexenio $y$, al mismo tiempo, de una de las aportaciones más innovadoras al constitucionalismo de la época, que salvo el antecedente fugaz de la Constitución republicana francesa de 1848 (art. 24), no había plasmado constitucionalmente el derecho al sufragio en los términos que lo hacía el referido art. 16 de nuestra Constitución de 1869 (la Constitución belga de 1831 no contiene, a este respecto, ninguna disposición equiparable). De esta forma, las Cámaras parlamentarias experimentan una reconfiguración de signo democrático que no puede ser obviada en el proceso en curso de implantación y asentamiento del constitucionalismo democrático en este período.

\subsection{El Rey y los ministros}

Una de las cuestiones centrales a las que debía dar respuesta el constituyente de 1869 era la (re)configuración de la Monarquía de acuerdo con los nuevos criterios democráticos emanados de la revolución de 1868. Conviene recordar que la institución monárquica es, durante esta época, el elemento central del Estado y de su configuración depende la del sistema político en su conjunto; en particular por lo que se refiere al proceso de parlamentarización de la Monarquía que se está desarrollando a partir de las experiencias constitucionales de 1830 en Francia, de 1831 en Bélgica ( $y$ también de 1837 en España). A ello hay que añadir que, en nuestro caso, la revolución de 1868 va dirigida directamente contra el régimen monárquico isabelino $y$, por tanto, la cuestión monárquica ocupará un lugar central en las preocupaciones del constituyente al diseñar el nuevo sistema institucional.

Así se puso de manifiesto en el intenso debate que suscitó este tema en las Cortes Constituyentes, en el que se plantea la alternativa republicana si bien finalmente acabará prevaleciendo por amplia mayoría el mantenimiento de la forma monárquica77. Ahora bien, se trata de una Monarquía distinta, como advierte Sánchez Agesta, que

77 El art. 33 de la Constitución, en el que se establecía la Monarquía como "forma de gobierno de la nación española», fue aprobado por 214 votos a favor, frente a. 71 en contra. La Constitución, en su conjunto, por 214 votos a favor, 55 en contra y la abstención de los tradicionalistas. 
es bautizada por sus propios promotores como "Monarquía democrática" y a la que se define, según el referido autor, "con términos hasta ese momento inéditos en el derecho constitucional español como la forma de gobierno de la nación española. La afirmación de la Monarquía como un poder constituido al definir la forma de gobierno no puede ser más neta", concluyendo que "se acepta la Monarquía como una forma de gobierno circunstancial, pasajera, como una concesión a estados de opinión y a costumbres políticamente arraigadas $^{78}$.

Esta nueva concepción de la Monarquía como poder constituido y como forma de gobierno, que tendrá reflejo expreso en el propio texto constitucional (preámbulo y art. 33) va a configurar la institución monárquica y a su titular, el Rey, con rasgos que difieren sensiblemente de los que habían sido característicos en el constitucionalismo histórico precedente, tanto por lo que se refiere a la figura del monarca en sí misma como en lo que concierne a la relación con otros poderes, especialmente el legislativo y el ejecutivo. Es precisamente en esta reordenación de las relaciones entre los poderes, en los términos que precisa el texto constitucional de 1869 , donde puede apreciarse con nitidez las expectativas de parlamentarización que se abren para la Monarquía refundada tras el triunfo de la revolución de 1868.

A la hora de rediseñar el esquema de relaciones entre los poderes, tal y como pretendía el constituyente de 1869, éste no podía ignorar las experiencias ya ensayadas en otros países. Pero si en otras cuestiones, como las ya vistas relativas a la formulación de la declaración de derechos o la configuración de las Cámaras, las referencias constitucionales exteriores podían ser variadas (fundamentalmente la Constitución americana o la francesa de 1848), en el caso concreto de la configuración de la institución monárquica desde una perspectiva parlamentaria, el único modelo viable era, aparte de la excepcional singularidad británica, el que proporcionaba la Constitución belga de 1831; texto éste que, por otra parte, ya había dejado notar su influjo en la Constitución de 1837 y en la nonata de 185679 .

El diseño constitucional de la Monarquía en Bélgica presenta, además, una singular característica coincidente con España como es,

78 L. SÁnChez Agesta: Historia del constitucionalismo español..., op. cit., pág. 287.

79 Vid. al respecto las ya referidas obras de A. COLOMER: El sistema politico de la Constitución española de 1837, op. cit., e I. CASANOVA: Aproximación a la Constitución nonnata de 1856, op. cit. 
aparte del signo marcadamente liberal de la revolución que precede inmediatamente (1830 en Bélgica; 1868 en España) a la elaboración de ambos textos constitucionales (1831 y 1869, respectivamente), el hecho inédito de que la Constitución fuese aprobada antes de que se eligiese por las propias Cámaras al Monarca ${ }^{80}$. De esta forma, el constituyente está libre de todo condicionante previo al perfilar la institución monárquica, que puede ser así configurada constitucionalmente ex novo. La concurrencia coincidente, en Bélgica y en España, de estas singulares circunstancias es un factor a tener en cuenta para explicar las importantes similitudes que pueden observarse en la configuración constitucional de la Monarquia en ambos casos.

Esta reconfiguración constituyente de la Monarquía en 1869 no impide que sigan persistiendo elementos propios del modelo anterior, vigente a partir de 1837. No obstante, hay que reiterar una vez más que este último ya había sido receptor del influjo de la Constitución belga de 1831 (y ésta, a su vez, de la Charte orleanista de 1830). Así, aunque las disposiciones relativas al Rey (Tít. IV, arts. 67-76) son, en gran parte, reproducción de las que ya la Constitución de 1837 dedicaba a esta

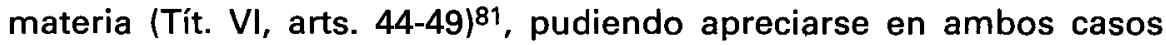
importantes similitudes, $y$ hasta coincidencias, con la regulación que la Constitución belga hace de la figura del Rey (arts. 60-85), hay que puntualizar que esos mismos poderes reales se insertan en un marco constitucional distinto, en el que la Monarquía se configura como una forma de gobierno (art. 33), en abierto contraste con la situación anterior. Asimismo, pasará a ser un poder constituido, privada de la potestad constituyente que ostentaba hasta entonces, como se pone de manifiesto en el Preámbulo constitucional al atribuir el poder constituyente a "la Nación española y, en su nombre, a las Cortes Constituyentes", así como en la disposición que constitucionaliza el principio de soberanía nacional, fuente de todos los poderes (art. 32). Por último, el propio texto constitucional, que atribuye el poder ejecutivo al Rey, prevé expresamente que éste "lo ejerce por medio de sus ministros» (art. 35).

El nuevo marco constitucional conformado por las referidas disposiciones reubica la institución monárquica en el conjunto del siste-

80 En Bélgica, la Constitución se aprueba en Febrero de 1831 y el Rey es elegido por el Congreso belga varios meses después, en junio del mismo año. En España, la Constitución se aprueba en junio de 1869 y la elección del Rey se demora más de un año, hasta noviembre de 1870 .

81 Cfr. A. CARro: La Constitución española de 1869, op. cit., págs. 138 y 317 y ss. 
ma institucional, aunque formalmente persistan, como ya se ha dicho, buena parte de los elementos del modelo precedente ${ }^{82}$. A ellos hay que añadir, en cualquier caso, otros nuevos que hacen su aparición por primera vez y en los que puede detectarse también la influencia belga. Cabe reseñar, a este respecto, la obligatoriedad de la sanción real de las leyes (art. 34 CE 1869; art. 69 CB 1831), sin que el Rey pueda oponer veto alguno como ocurría hasta entonces (art. 39 CE 1837), lo que constituye un paso importante en el proceso de parlamentarización de la Monarquía. Por otra parte, algunas prerrogativas reales van a sufrir limitaciones; asi, será preciso la autorización previa al monarca, mediante ley especial "para incorporar cualquier otro territorio al territorio español" (art. 74.2. ${ }^{\circ} \mathrm{CE}$; a, en relación con el art. $68 \mathrm{CB}$ ); y también, en relación con los Tratados suscritos por el Rey, la previsión de que "en ningún caso los artículos secretos de un Tratado pueden derogar los públicos" (art. 74 in fine $\mathrm{CE}$, en relación con el art. $68 \mathrm{CB}$ ).

Interesa llamar la atención sobre el hecho insólito, ya reseñado, de que la designación del titular de la Corona, y de la propia dinastía que sustituirá a la reinante hasta entonces, es posterior a la aprobación de la Constitución, acentuando así el carácter de poder constituido de la Monarquía. Esta atípica situación - una Monarquía sin Reyobliga al constituyente a prever una futura ley «para elegir la persona del Rey" (Disposición transitoria 1. ${ }^{a}$ ) que "formará parte de la Constitución". Fue necesario esperar más de un año hasta que se aprobó la referida ley ${ }^{83}$ y poder cumplir así las previsiones constitucionales de elección del nuevo Rey, que tras un accidentado proceso de selección de candidatos recayó en la persona de Amadeo de Saboya. Se trata, como puede observarse, de una Monarquía atípica en la que su titular es elegido, al margen de la línea dinástica, por el Parlamento.

Tan sólo en un caso se había producido una situación similar, tanto por lo que se refiere al diseño constitucional de la institución monárquica sin que existiese Rey como a la elección de éste una vez aprobada la Constitución. Es precisamente en Bélgica, donde también el proceso fue el mismo: tras elaborar y aprobar la Constitución del Reino de Bélgica (febrero 1831) se procede después a la a la elección por

82 Cfr. J. M. Porras: Principio democrático y función regia..., op. cit., pág. 131.

83 Ley de 10 de junio de 1870 . El texto íntegro de esta ley, que, según la Disposición Transitoria 1. ${ }^{a}$, "formará parte de la Constitución", puede verse en D. SEvilla Andrés: Constituciones y otras leyes..., op. cit., págs. 541-543. Para un breve comentario sobre esta ley, vid. F. FeRnÁndez-SEgADo: Constituciones históricas..., op. cit., págs. 311 y 312. 
el Parlamento del titular de la Corona (junio 1831), que en este caso recaerá en la persona de Leopoldo de Sajonia-Coburgo ${ }^{84}$. No es de extrañar que dados estas sorprendentes coincidencias en los origenes constitucionales de las Monarquías belga (en 1831) y española (en 1869-70), su configuración constitucional presente también apreciables similitudes en ambos casos.

Seguidamente, la Constitución se ocupa brevemente (Tít. VI, arts. 87-91) de "los ministros"; se refiere a ellos, individualmente, sin hacer mención al Gobierno o al Consejo de Ministros como órgano colegiado, a los que, sin embargo, se refiere como tales en otras ocasiones ${ }^{85}$. De las cuatro disposiciones dedicadas a este tema, las dos primeras reproducen previsiones ya existentes anteriormente como el refrendo ministerial de los actos del Rey (art. 87 CE 1869; art. 61 CE 1837) o la compatibilidad entre el cargo ministerial y el parlamentario, si bien reforzándola en este último caso mediante la prohibición de "asistir a las sesiones de las Cortes los Ministros que no pertenezcan a uno de los cuerpos legisladores" (art. 88), lo que contribuye a acentuar los rasgos parlamentarios en las relaciones entre el Gobierno y las Cámaras. Las otras dos son nuevas, inspiradas directamente en la Constitución belga, y se refieren a las responsabilidades penales de los Ministros. A este respecto, se prevé un procedimiento de impeachment, similar al anglosajón, en el que el Congreso formula la acusación y el Senado actúa como órgano juzgador (en el sistema belga es el Tribunal Supremo el órgano juzgador). $Y$ por lo que se refiere al indulto de un Ministro por el Rey, se requiere "la petición de uno de los cuerpos colegisladores» (art. 90 CE 1869, que reproduce el art. 91 de la Constitución belga).

Aunque no insertas en este Título que estamos comentando referente a "los Ministros", hay dos disposiciones nuevas que inciden directamente sobre éstos. La primera, a la que ya hemos aludido al referirnos a la configuración constitucional de los poderes del Estado (Tít. II), explicita que el poder ejecutivo, cuya titularidad reside en el Rey, "lo ejerce por medio de sus Ministros» (art. 35); esta puntualización iba dirigida a evitar cualquier ambigüedad al respecto $y$, sobre

84 En Bélgica, el Rey Leopoldo de Sajonia-Coburgo fue elegido por el Congreso Nacional el 4 de junio de 1831 por 152 votos sobre 196 parlamentarios. En España, Amadeo de Saboya fue elegido por las Cortes el 16 de noviembre de 1870 por 191 votos sobre 344 diputados.

85 Cfr. J. TOMÁs VILLARROYA: Breve historia del constitucionalismo..., op. cit., pág. 94. 
todo, como señala Villarroya ${ }^{86}$, a hacer frente al ejercicio directo y personal del poder ejecutivo por el monarca, tal y como había venido ocurriendo bajo el régimen isabelino (y seguirá ocurriendo después bajo el régimen de la restauración alfonsina). La otra disposición, inserta en el Tít. III, referente al poder legislativo, constitucionalizaba la responsabilidad política (y no sólo penal) de los Ministros. Al reconocer el derecho de interpelación de cada uno de los miembros de las Cámaras y el de censura de los cuerpos colegisladores (art. 53). Se trata, sin duda, de una de las novedades más destacables, cuyo antecedente puede encontrarse también en la Constitución belga (el art. 63 alude a la responsabilidad de los ministros) y que supone una contribución decisiva a la parlamentarización de las relaciones entre el legislativo y el ejecutivo.

\section{La remodelación del poder judicial}

El poder judicial experimenta una importante remodelación en relación con la situación anterior. Si bien en el Título relativo a esta materia (Tít. VII, arts. 91-98) pueden apreciarse elementos que ya estaban presentes en las Constituciones precedentes de 1837 y 1845, aparecen también importantes novedades que no deben pasar inadvertidas. La primera, en el propio encabezamiento de este Título: "Del poder judicial», recuperando asi esta noción (ya contenida en la Constitución de 1837) que había sido sustituida en la precedente Constitución de 1845 por la de "Administración de Justicia" (Tít. X).

Pero el rasgo más reseñable es el fortalecimiento que experimenta el poder judicial ${ }^{87}$ en su conjunto, en particular frente al ejecutivo, al que había venido estando subordinado de hecho. Es ilustrativo al respecto que en el curso del debate constituyente se llegara incluso a proponer la eliminación de la referencia al Rey, como titular del poder ejecutivo, en la fórmula tradicional "la justicia se administra en nombre del Rey" (art. 91) para subrayar así la independencia del poder judicial. Pero independientemente de esta propuesta frustrada,

86 J. TOMÁs VILLARROYA, op. cit.

87 Según A. CARro: La Cónstitución española de 1869, op. cit., pág. 135, se trata, junto con la declaración de derechos, de la aportación más significativa de la Constitución de 1869. 
la independencia judicial hallará plasmación constitucional a través de la introducción de nuevas disposiciones relativas a la designación de los jueces y magistrados, cuestión que hasta entonces no había sido objeto de referencia constitucional alguna.

A esta cuestión se dedica el art. 94, enteramente nuevo y uno de los más discutidos ${ }^{88}$. En él, además de introducir la importante novedad de que el ingreso en la carrera judicial debía de ser por oposición, se establece el marco pára el nombramiento por el Rey de los jueces y magistrados «a propuesta del Consejo de Estado y con arreglo a la ley orgánica de tribunales», y no a propuesta del Ministerio de Gracia y Justicia como ocurría hasta entonces; ello contribuia a desgubernamentalizar el nombramiento de jueces y magistrados $y$, en consecuencia, a reforzar la independencia del poder judicial. Hay que decir que aunque esta disposición carece de precedentes en nuestros anteriores textos constitucionales, sí puede hallarse una disposición semejante en la Constitución belga de 1831 (art. 99); es preciso puntualizar que la semejanza se refiere a la referencia constitucional al nombramiento de los jueces y no a la forma de nombramiento, que según la referida disposición constitucional belga no se articula a través del Consejo de Estado sino de los órganos representativos a los distintos niveles $y$ de los propios órganos judiciales.

Interesa subrayar la amplia cobertura constitucional que el texto de 1869 proporciona al Consejo de Estado, no sólo en el nombramiento de los jueces y magistrados en lo términos señalados sino también en su destitución y traslado (art. 95) y en los ascensos (art. 97); en todos los casos se prevé expresamente la preceptiva consulta al Consejo de Estado. Si bien estas cuestiones, como señala Carro, pueden ser más propias de una Ley Orgánica del Poder Judicial que de un texto constitucional89, su inclusión en él se justifica por la preocupación del constituyente de 1869 por desgubernamentalizar el poder judicial, neutralizando la intervención del poder ejecutivo en él, mediante la interposición de una instancia aparentemente más imparcial como el Consejo de Estado. En cualquier caso, es una novedad que carece de antecedentes tanto en los textos precedentes de 1837 y 1845 como en el constitucionalismo comparado de la época.

88 Un comentario sobre este controvertido artículo, «aprobado por la mayoria más exigua de toda la legislatura" (111 votos frente a 105) según A. CARRO, puede verse en op. cit. de este autor, págs. 356-359.

89 A. CARRO, op. cit., pág. 137. 
Sí va a tener, en cambio, precedentes constitucionales la constitucionalización expresa del jurado (art. 93). Si bien el la Constitución de 1837 había una referencia confusa a él, ubicada no en el Título relativo al Poder judicial sino en la Disposición adicional $1 .{ }^{a}$, que remite a futuras leyes para «determinar la época y el modo en que ha de establecersen, referencia que queda suprimida en la Constitución de 1845, los textos constitucionales de otros paises de nuestro entorno sí contemplaban esta institución. Además de Gran Bretaña y USA, donde ha tenido siempre fuerte arraigo, también en el constitucionalismo continental de la época puede detectarse su presencia; tal es el caso de la Charte orleanista de 1830, si bien condicionada a «los cambios que una larga experiencia juzgue necesarios" (art. 56); y de forma más clara en la Constitución belga de 1831 (art. 98) y en la Constitución republicana francesa de 1848 (arts. 82, 83 y 84). En nuestra Constitución de 1869 presentaba características peculiares distinguiendo entre los delitos políticos, que serían en todo caso objeto de juicio por jurados, siguiendo en este punto los criterios de la Constitución republicana francesa de 1848 (art. 83), y los delitos comunes, de los que se ocuparia el jurado sólo en los casos que determine la ley (art. 93).

Otra novedad es la función que se atribuye expresamente a los Tribunales como garantes del cumplimiento de las leyes frente a cualquier eventual infracción proveniente de la potestad reglamentaria. Esta disposición constitucional (art. 92), que refleja la desconfianza del constituyente ante posibles extralimitaciones del ejecutivo y que carece de precedentes en nuestros anteriores textos constitucionales, procede directamente de la Constitución belga, reproduciendo en los mismos términos su art. 107.

Algunos comentaristas de la Constitución de 1869 han circunscrito la influencia exterior en la configuración del poder judicial al modelo anglosajón ${ }^{90}$. Sin ignorar el indudable influjo que ha ejercido este modelo, fundamentalmente el británico más que el norteamericano ya que este último, además de estar basado en aquél, introduce elementos específicos de carácter federal ${ }^{91}$ que no tienen correspondencia en el sistema de 1869 (sí la tendrán en el proyecto constitucional federal de 1873), no cabe desconocer el referente que supusieron para el constituyente de 1869 otros modelos constitucionales europeos como el francés de 1848 y el belga de 1831 . Hay que puntualizar,

90 En este sentido, vid. A. CARro, op. cit, págs. 131 y 135.

91 Cfr. J. OltRA: La influencia norteamericana..., op. cit., pág. 131. 
no obstante, que también pueden apreciarse notables diferencias, como la inexplicable ausencia de referencia alguna al máximo órgano del poder judicial, el Tribunal Supremo, a diferencia de la Constitución belga, que se refiere expresamente a él (art. 95), además de a los Tribunales de Apelación (art. 104); e igualmente la americana (art. 3), así como también la francesa de 1848 , que no se olvida de aludir al Tribunal de Casación y al Alto Tribunal de Justicia (arts. 85 y ss. y arts. 91 y ss.).

\section{Las instituciones locales}

Aunque todas las Constituciones españolas, desde la de Cádiz de 1812, dedicaban algunas de sus disposiciones a las instituciones locales - municipios y provincias - la de 1869 introduce algunas novedades dignas de reseñar. En primer lugar, hay una referencia expresa a ellas, como ya se señaló en su momento (ver supra), en el Título que se refiere a "Los Poderes", aludiendo, en este marco general, a los intereses peculiares que les son propios y cuya gestión corresponde a los Ayuntamientos y Diputaciones. Esta disposición de carácter general, cuya ubicación en el texto constitucional en el Título relativo a los poderes no es irrelevante, queda completada con un Título específico de artículo único (Tít. VIII; art. 99) en el que se hace referencia a las organización y atribuciones de las Diputaciones y Ayuntamientos, remitiendo a una ley para su concreción y desarrollo. Pero a diferencia de los textos constitucionales precedentes (1837 y 1845), que se limitaban a hacer esta remisión a la ley sin más precisiones, la Constitución de 1869 introduce la importante novedad de constitucionalizar expresamente los principios básicos a los que ha de ajustarse la legislación sobre la materia92, estableciendo un listado en el que se hace referencia al gobierno y dirección de los intereses peculiares locales, la publicidad de las sesiones de las Corporaciones locales, la publicación de los Presupuestos y cuentas, la intervención tutelar del Rey, y en su caso las Cortes, para impedir que una eventual extralimitación en sus atribuciones vulnere los intereses generales, y la determinación de sus facultades en materia de impuestos. Es preciso reseñar que este listado reproduce, a veces con los mismos términos, el listado que también con el mismo fin establece el art. 108 de la Constitución belga, lo 
que pone de manifiesto una vez más la influencia que ésta ejerció sobre el constituyente de 1869 y la sintonía existente entre ambos textos constitucionales.

\section{La reforma constitucional}

Queda, por último, referirnos a la reforma constitucional, cuestión a la que se dedica un Título específico (Tít.XI; arts. 110-112) con el que se cierra el texto de 1869. La primera observación que hay que realizar es que se trata de un pasaje constitucional enteramente nuevo, que carece de antecedentes en los textos constitucionales precedentes de 1837 y 1845 (no asi en la nonata de 1856, que sí se ocupaba de este tema en términos similares; Tít. XV, arts. 87 y ss.). Habrá que remontarse al primer constitucionalismo de 1812 para hallar en él (Tít. X, Arts. 372-384) los únicos antecedentes históricos (la nonata de 1856 no llegó a tener vigencia efectiva) sobre esta materia.

Como ya se ha señalado en su momento, al referirnos a este mismo tema en la Constitución belga (ver supra), se trata de una cuestión clave ${ }^{93}$ que, más allá de los aspectos procedimentales en la forma de realizar la revisión, guarda relación con la titularidad del poder constituyente $y$, más concretamente, con la posición del monarca, compartiendo la cotitularidad del mismo o como poder constituido. Era ésta una cuestión que no sólo en España, donde nuestro constitucionalismo histórico había venido proporcionando cobertura a la tesis de la soberanía compartida entre el Rey y las Cortes, sino también en la Europa de la época, donde también este tema era objeto de polémica, tenía la máxima actualidad y había dado lugar a respuestas constitucionales dispares. A este respecto, el constituyente de 1869 se decantará por una opción netamente parlamentaria, reservando a las Cortes la decisión en materia de revisión constitucional.

De acuerdo con el procedimiento previsto en la propia Constitución para su reforma, la iniciativa corresponde bien a las mismas Cortes o al Rey, cuya participación en ef proceso de revisión queda limitada a la eventual propuesta en este sentido (art. 110) y a la preceptiva disolución de las Cámaras y convocatoria de nuevas Cortes (art. 111)

93 Como ya se ha reseñado (ver supra), para K. LOEWENSTEIn (Teoria de la Constitución, op. cit.) es un criterio a tener en cuenta para determinar la naturaleza del régimen político. 
tras la declaración de revisión constitucional. Las nuevas Cámaras elegidas tendrán que pronunciarse sobre la declaración de revisión de las anteriores $y$ decidir finalmente sobre los términos en que se efectúa la reforma constitucional. Se trata del mismo procedimiento previsto en la Constitución belga (art. 131) - declaración de revisión, disolución de las Cámaras y elección de unas nuevas que se pronuncian sobre esta declaración y aprueban la reforma - que, a diferencia de sus coetáneas europeas de la época, introducía criterios de rigidez constitucional ${ }^{94}$.

Dos puntos es preciso reseñar, sin embargo, en los que no hay coincidencia. En nuestra Constitución de 1869 no se exige un quórum especial de presencia en las Cámaras ni ninguna mayoría cualificada para aprobar la reforma, como se hace en la Constitución belga de 1831 ( $2 / 3$ en ambos casos) y como será luego práctica usual en el constitucionalismo comparado para reforzar la rigidez constitucional, que en nuestro caso será más atenuada. Por otra parte, el Rey tiene un papel más limitado en nuestra Constitución de 1869 , donde su participación en el proceso de revisión se limita a la eventual formulación de una propuesta en este sentido, mientras que en la belga, además de la iniciativa, la aprobación de la reforma por la Cámaras ha de hacerse "de común acuerdo con el Rey". En cualquier caso, y a pesar de las diferencias procedimentales señaladas relativas a las mayorías requeridas y a la participación del Rey, se introducen criterios constitucional que, también en esta ocasión, tienen como referente el modelo belga de revisión constitucional.

94 Vid. P. DE VEGA: La reforma constitucional..., op. cit., en particular, el apartado "El significado de la ausencia de un procedimiento de reforma», págs. 81 y ss. 